تصميم وحدة في النانو تكنولوجي وتطبيقاتها قائمة على التعلم البنائي لتتمية مهارات التفكير المستقبلي

$$
\text { لتلاميذ الصف الثاني الإعدادي }
$$

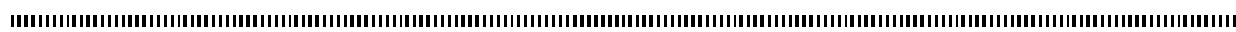

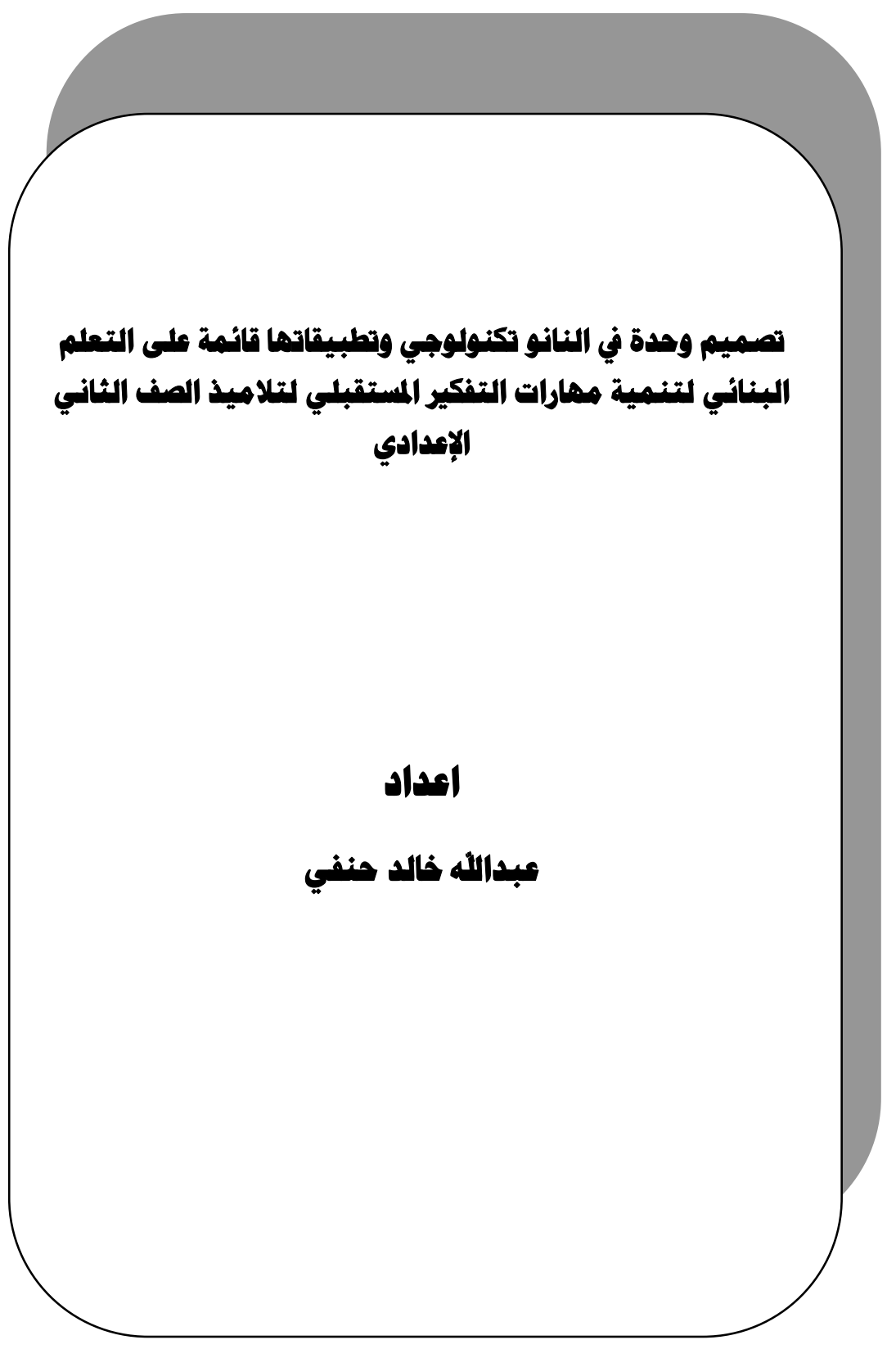

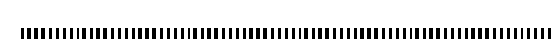

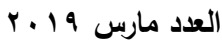

11

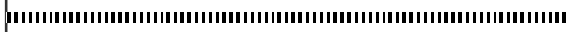
المجلد الخامس والعشرون 


$$
\text { تصميم وحدة في النانو تكنولوجي وتطبيقاتها قائمة على التعلم البنائي لتتمية مهارات التفكير المستقبلي لتلاميذ الصف الثاني الإعدادي }
$$

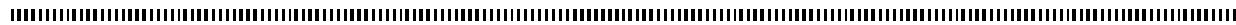

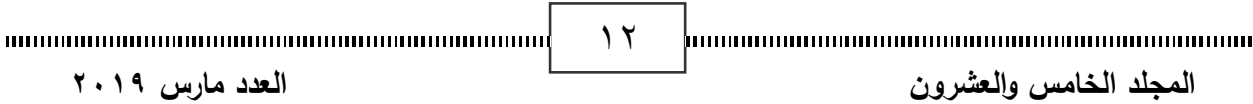


تصميم وحدة في النانو تكنولوجي وتطبيقاتها قائمة على التعلم البنائي لتتمية مهارات التفكير المستقبلي

$$
\text { لتلاميذ الصف الثاني الإعدادي }
$$

|

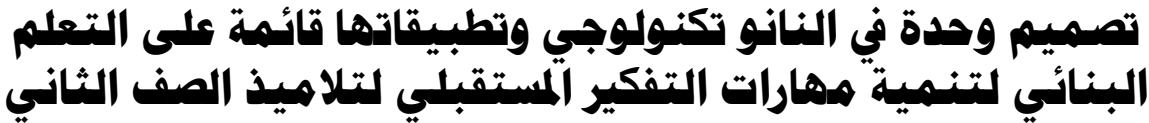

\section{الإعدادي الإدي}

\section{عبدالاله خالد هنفي}

\section{همقدمة:}

يتميز هذا العصر بالتقدم العلمي الهائل والمتسارع في شتى جوانب المعرفة، وكذلك في عدد الاكتشافات والمخترعات في مختلف الجوانب والتطبيقات، وقد أحدث ما شهدته

الحضارة الإنسانية من قفزات وطفرات علمية تغييراً جذرياً شمل معظم نواحي الحياة

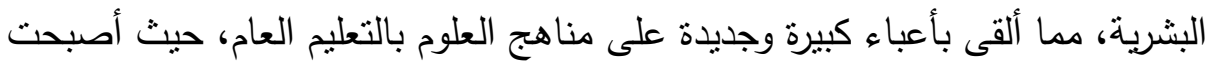

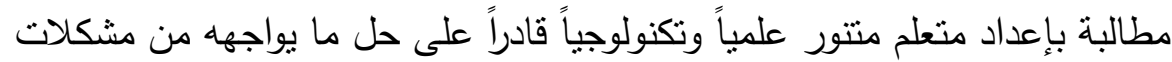

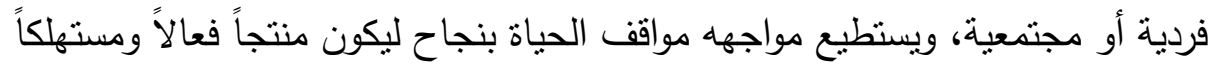
مستنيراً

وتعد علوم النانوتكنولوجي من أحدث ما يدور في العالم من تطور علمي وتقدم تكنولوجي، فعلى مدى السنوات القليلة السابقة احتلت تكنولوجيا النانو مكانة مرموقة في

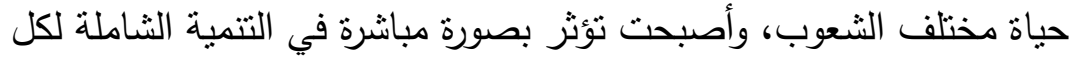
المجتمعات. فهذه التقنية الواعدة تبشر بقزة هائلة في شتى فروع العلم وتساعدنا من

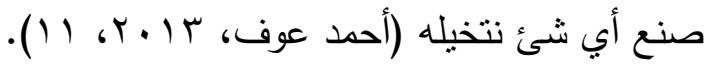
والنانو (Nano) كلمة يونانية الأصل تعني قزم (Dwarf) وتستخدم للتعبير عن

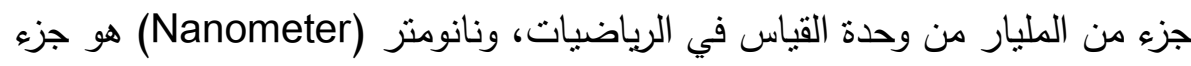

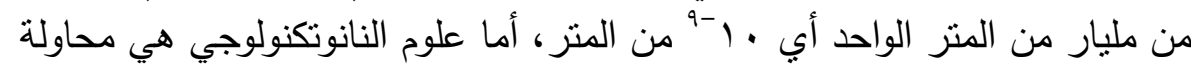

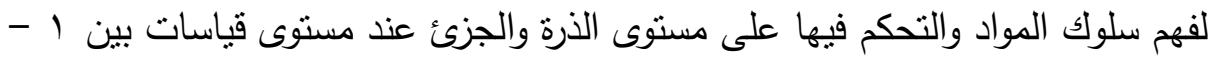
. . . نانومتر بهدف ابتكار تركيبات وأجهزة ونظم صغيرة الحجم ذات خصائص ووظائف جديدة "المبادرة القومية للنانوتكنولوجي".

(National Nanotechnology Initiative, 2006, 22) 
تصميم وحدة في النانو تكنولوجي وتطبيقاتها قائمة على التعلم البنائي لتتمية مهارات التفكير المستقبلي

$$
\text { لتلاميذ الصف الثاني الإعدادي }
$$

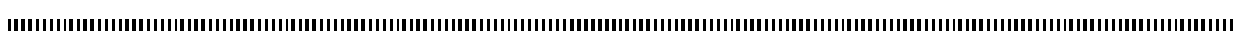

وبدخل علم النانوتكنولوجي وتطبيقاته في كافة مجالات الحياة كما أشار إليها (محمد

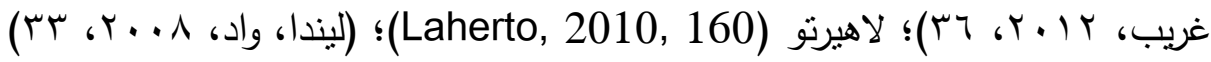
فيما بلى :

الطاقة النانوية: تستخدم تقنية النانو في مجالات عدة للطاقة التي تتمثل في

التخزين والتحويل وتحسين التصنيع، فهناك المصباح الثنائي الذي يؤدي إلى ترشيد

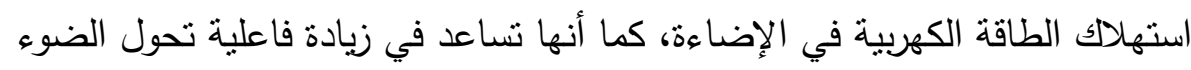
الحراري من خلال استخدام الهياكل

النانوية من الحزم ذات الفجوات، وتعمل تقنية النانو على تحسين كفاءة محرك الاحتراق الداخلي، وذللك بتطوير مواد جزيئية نانوبة يتم رشها على السطح فتحوله إلى ونى مصدر للطاقة الثمسية وبالإضافة إلى هذا تعد الطاقة النانوية صديقة للبيئة حيث إنها فعالة في تقليل الملوثات الصادرة من محرك الاحتراق من خلال مرشحات مسام نانوية تعمل على تتقية وتتظيف العوادم عن طريق محولات محفزة وجزيئات معادن نبيلة نانوية. الطب النانوي: من أهم خصائص تقنيات النانو أنها تسهم بشكل كبير في علاج أمراض السرطان باستخدام الجسيمات النانوية في التصوير بالرنين المغناطيسي؛ لتحديد موقع الأورام السرطانية بدقة عالية، بالإضافة إلى تقنية توصيل الأدوبة والعقاقير باستخدام الأنابيب النانومترية.

بمسريات النـانو: تم صناعة نظارات شمسية مصممة بطلاءات سطحية مقاومـة للخدش باستخدام مكونات نانوية، وكذلك بصريات النانو التي تعمل على الزبادة في دقة تصحيح بؤرة العين وتستخدم في صناعة قرنية العين.

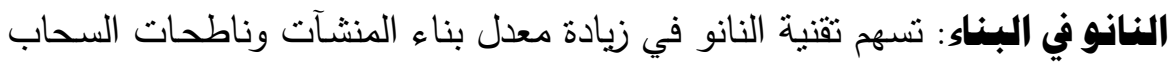

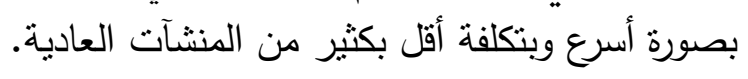

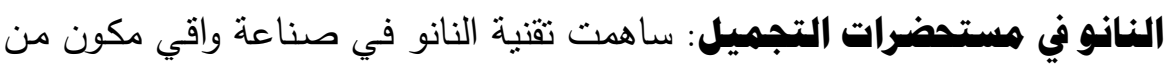

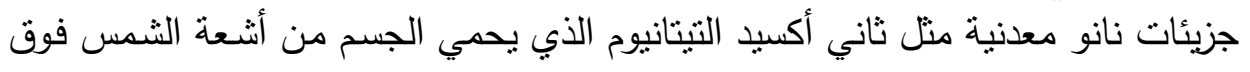
البنفسجية الضارة.

ألياف النـانه: نستخدم في صناعة أقمشة مقاومة للمياه والبقع والانكماش، وأيضـاً صناعة مرشحات تثقية المياه والهواء. وتثير بعض الدراسات إلى ضرورة دمج مفاهيم النانو وتطبيقاتها بالمناهج الدراسية

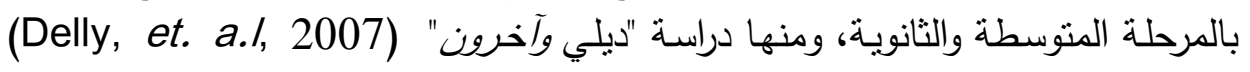

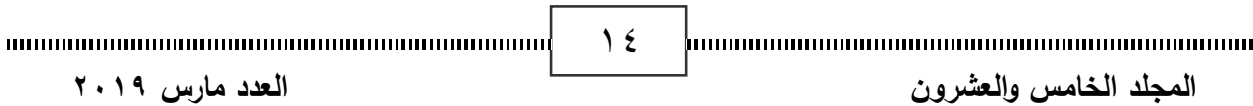


تصميم وحدة في النانو تكنولوجي وتطبيقاتها قائمة على التعلم البنائي لتتمية مهارات التفكير المستقبلي

$$
\text { لتلاميذ الصف الثاني الإعدادي }
$$

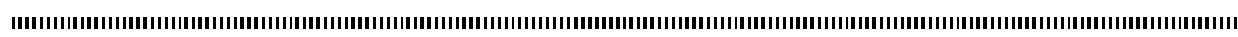

التي هدفت دمـج مفـاهيم علوم النـانوتكنولوجي بالمنـاهج الدراسية المقررة على المرحلـة المتوسطة من التعليم الأساسي والمرحلة الثانوية، واقتراح مجموعة من الأنشطة وخطط

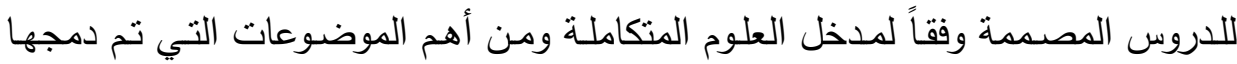
نظائر الكربون والمسح الضوئي والمنتجات النانوية الموجودة بالسوق.

ونظراً لأهمية تضمين تطبيقات النانوتكنولوجي في مناهج العلوم فقد أجريت العديد

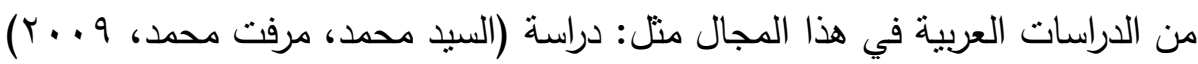

التي استهدفت تقويم منهج العلوم بالمرحلة الإعدادية في ضوء بعض دضه مفاهيم

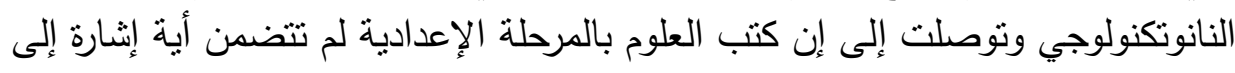
مفاهيم النانو ومجالاتها التطبيقية، وتوضتح دراسة (نوال محمد، ب ( ب) إن مناهج التعليم

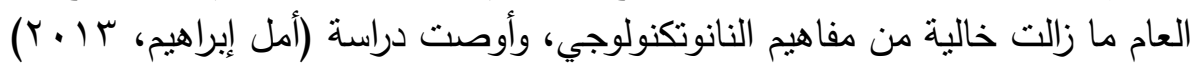

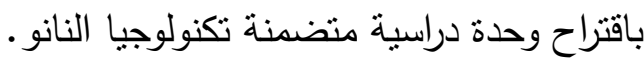

وإن تعلم مهارات التفكير عامة ومهارات التفكير المستقبلي خاصة، يعد بمثابة تزويد

الفرد بالأدوات التي يحتاجها حتى يتمكن من التعامل بفاعلية مع أنواع مختلفة من المعلومات والمتغيرات التي يأتي بها المستقبل لذلك لابد من تضمين مهارات التفكير في المناهج الدراسية، وإعادة هيكلة المناهج التعليمية في صورة جديدة، والذي يتطلب ضرئبن ضرورة

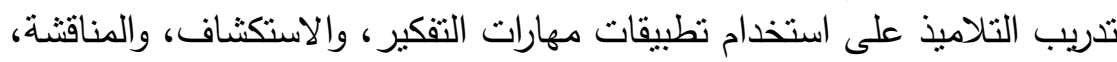
والتحليل، والدفاع عن الآراء، والمعتقدات الثخصية والعمليات العقلية المعرفية المختلفة

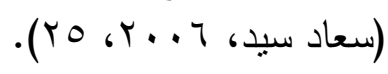

ويؤكد جان بياجيه "Jan page" وبراندت "Brandt" إن الاهتمام بتتمية التفكير المستقبلي يتطلب التأكيد على أهمية مراجعة شاملة للمناهج الدراسية، وأساليب العرض وإستراتيجيات التدريس، لتصبح ذات إهتمام بتتمية وفهم عمليات التغيير ، وتتمية مهارات

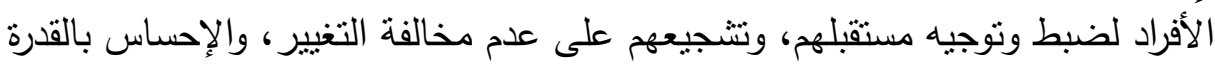
على صياغة الأحداث والتأثير فيها بصورة مباشرة، فمنل هذا النوع من التفكير بشجع

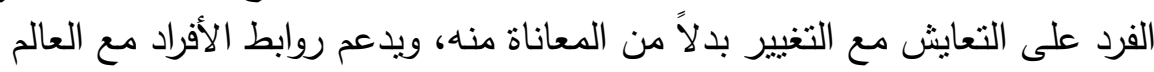
الخارجي وإجمالاً فإن الاهنمام بتنمية التفكير المستقبلي ومهاراته لدى التلاميذ يدعم Brandt, ) (Jan page, 1993, 132) (استعادة الثعور بالتحكم في الحياة المستقبلية .(R, 2000, 2

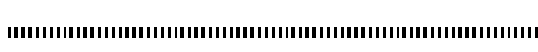

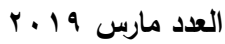

10

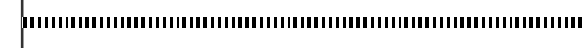
المجلد الخامس والعشرون 
تصميم وحدة في النانو تكنولوجي وتطبيقاتها قائمة على التعلم البنائي لتتمية مهارات التفكير المستقبلي

$$
\text { لتلاميذ الصف الثاني الإعدادي }
$$

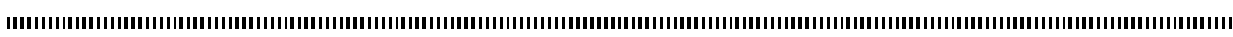

ويتضح مما سبق إن مجال النانوتكنولوجي وتطبيقاته مجال خصب لتتمية مهارات

$$
\text { التفكير المستقبلي لدى تلاميذ الصف الثاني الإعدادي. }
$$

والتفكير المستقبلي يعتمد بصورة أساسية على عدد من العمليات العقلية العليا، فمن خلال تحليل بنيته من الداخل، تم التوصل إلى عدة مهارات أساسية نتكل بنية التفكير

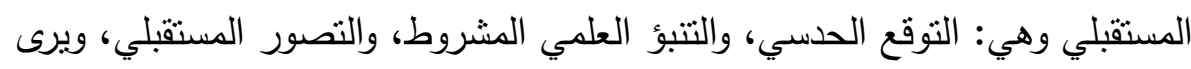
الباحث أنه يمكن تتمية هذه المهارات لتلاميذ الصف الثاني الإعدادي من خلافل تصميم وحدة في النانوتكنولوجي وتطبيقاتها قائمة على التعلم البنائي، وفيما يلي شرح تقصيلي لكل مهاراة على حده:

ا ـ همهارة التوقع الهدسي: الحدس من الهبات الجمة الممنوحة للإنسان، يولد

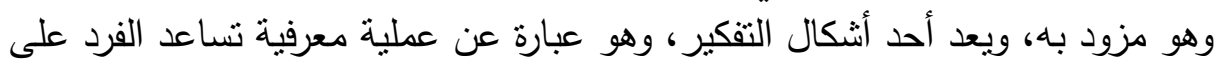

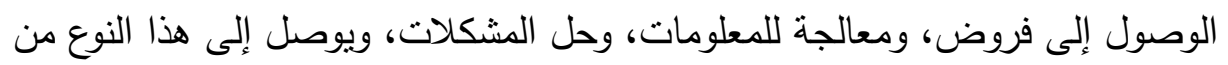
التفكير على شكل قفز تدريجي للخطوات التي يتصف بها التفكير التحليلي، فهو إدراك للمعنى أو الموقف الكلي وفهمه دون الإعتماد على خطوات التحليل المنطقي (يوسف

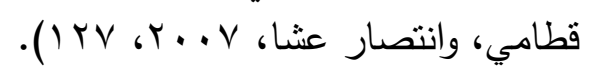

r. همهارة التنبـؤ العلمي المشروط: يقصد بها قدرة التلمبذ على توقع أحداث

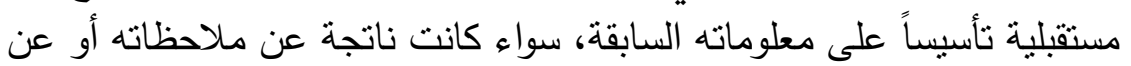

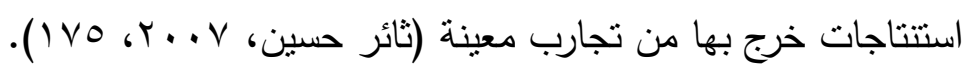

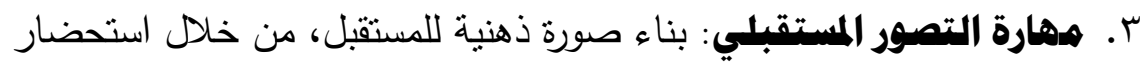
صور من الماضي لإختراع أثنياء جديدة، ويستخدم للوصول إلى ما وراء الحقيقة والواقع،

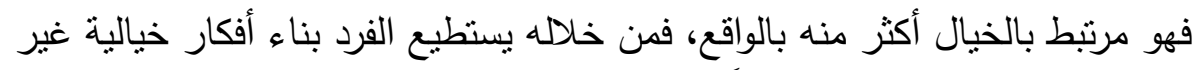
(ثائر متوقعة قد تصبح بالمستقبل أفكاراً واقعية وضرورية ومفيدة للمجتهع

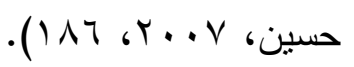

هشكلة البمث:

لقد استدل الباحث على وجود مشكلة البحث من خلال ما يلى :

عمل الباحث كمعلم علوم بالمرحلة الإعدادية ومراجعة محتوى كتب العلوم المقررة

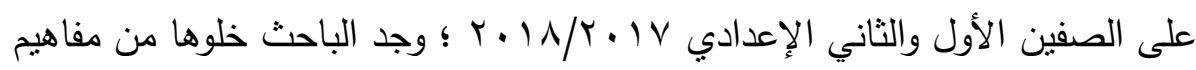


تصميم وحدة في النانو تكنولوجي وتطبيقاتها قائمة على التعلم البنائي لتتمية مهارات التفكير المستقبلي

$$
\text { لتلاميذ الصف الثاني الإعدادي }
$$

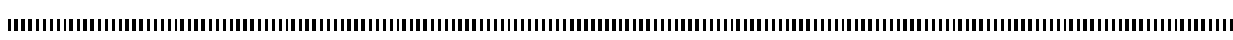

النانوتكنولوجي وتطبيقاتها في المجالات المختلفة التي تساعد على تتمية مهارات التفكير •

كما انعكس هذا القصور على التلامبذ حيث تبين ضعف فهمهم لمفاهيم النانو وتطبيقاتها المختلفة، وذللك من خلال قيام الباحث بإجراء دراسة استطلاعية هدفت إلى هيل

تعرف مدى معرفة التلاميذ لعلم النانوتكنولوجي وتطبيقاته التي تساعدهم على تتمية مهارات التفكير المستقبلي ؛ من خلال عمل استبانة على عدد (هب تلميذاً) من الصفين الثاني والثالث الإعدادي، وكانت النتيجة معظد التلامبذ لديهم ضعف في مهارات التفكير المستقبلي؛ مما أدى إلى إثارة اهتمامهم لدراسة علم النانوتكنولوجي وتطبيقاته المختلفة. وقام الباحث بالإطلاع على البحوث والدراسات السابقة التي سبق الإثارة إلبها في مقدمة البحث والتي أوضحت وجود مشكلة البحث والتي تتمثل في ضعف مواكبة مناهج

العلوم المقررة على تلاميذ المرحلة الإعدادية للتطورات الحديثة في العلوم الطبيعية وبخاصة علوم النانوتكنولوجي وتطبيقاتها المختلفة التي تسهم في تتمية مهارات التفكير المستقبلي لديهم.

\section{تتصدد مشكلة البمث في:}

قصور تتاول مناهج علوم المرحلة الإعدادية لعلم النانوتكنولوجي وتطبيقاته في المجالات المختلفة، مما أدى إلى ضعف مهارات التفكير المستقبلي لدى تلاميذ المرحلة الإعدادية، بالرغم من أهمية التفكير المستقبلي ومهاراته في ذلك العصر وحياتتا اليومية،

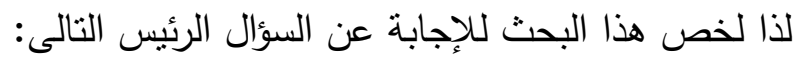

\section{ها فاعلية تصميه وحدة في النانوتكنولوجي وتطبيقاتها قائمة على التعلم}

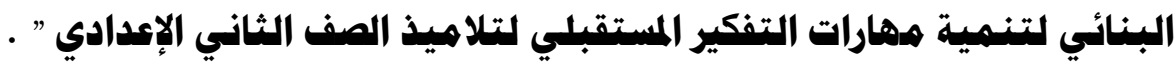

$$
\text { ويتقرع من هذا السؤال الرئيس عدداً من الأسئلة الفرعية: }
$$

ا ـ ما التصميم المقترح لوحدة تعليمية في النانوتكنولوجي وتطبيقاتها قائمة على التى التئي التعلم البنائي لتتمية مهارات التفكير المستقبلي لتلامبذ الصف الثاني الإعدادي لعيدي فئي r. ما تطبيقات النانوتكنولوجي المناسبة لتلاميذ الصف الثاني الإعدادي التي يمكن تضمينها بالوحدة المصممة؟ مان تصن 
تصميم وحدة في النانو تكنولوجي وتطبيقاتها قائمة على التعلم البنائي لتتمية مهارات التفكير المستقبلي

$$
\text { لتلاميذ الصف الثاني الإعدادي }
$$

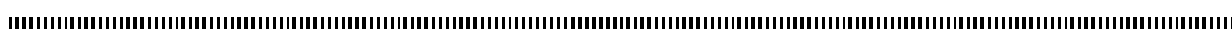

r. ما مهارات التفكير المستقبلي التي يمكن تتميتها لتلاميذ الصف الثاني

الإعدادي؟

ء. ـ ما فاعلية وحدة مصممة في النانوتكنولوجي وتطبيقاتها قائمة على التعلم البنائي

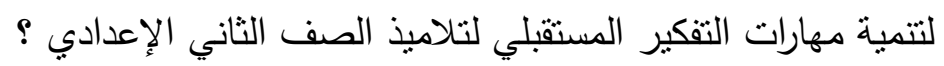

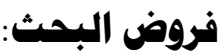

ا ـ بوجد فرق دال إحصائياً عند مستوى (1 . , • ) بين متوسط درجات تلاميذ

المجموعة التجربيية في التطبيقين القبلي والبعدي لمهارة التوقع الحدسي لصالح التطبيق

البعدي.

ץ . يوجد فرق دال إحصائياً عند مستوى ( ( , • ) بين متوسط درجات تلاميذ

المجموعة التجريبية في التطبيقين القبلي والبعدي لمهارة التبؤ العلمي المشروط لصالح التطبيق البعدي.

". يوجد فرق دال إحصائياً عند مستوى ( ( . • ) بين متوسط درجات تلاميذ

المجموعة التجريبية في التطبيقين القبلي والبعدي لمهارة التصور المستقبلي لصالح التطبيق البعدي.

ع. يوجد فرق دال إحصائياً عند مستوى ( ( . • ) بين متوسط درجات تلاميذ

المجموعة التجريبية في التطبيقين القبلي والبعدي لمقياس مهارات التفكير المستقبلي ككل لصالح التطبيق البعدي.

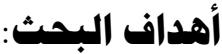

$$
\text { يهذف هذا البحث إلى : }
$$

ا ـ تصميم وحدة بمنهج العلوم للصف الثاني الإعدادي في النانوتكنولوجي

وتطبيقاتها قائمة على التعلم البنائي.

r . تحديد تطبيقات النانوتكنولوجي المناسبة لتلاميذ الصف الثاني الإعدادي التي

يمكن تضمينها بالوحدة المصممة.

r. تحديد مهارات التفكير المستقبلي التي يمكن تتميتها لتلاميذ الصف الثاني

$$
\text { الإعدادي. }
$$

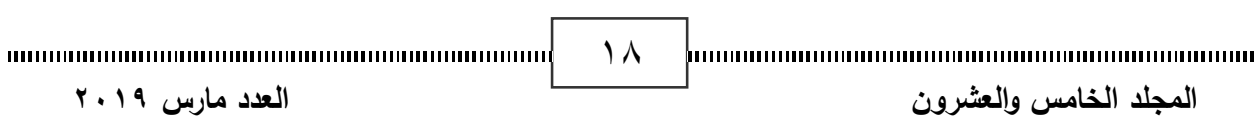


تصميم وحدة في النانو تكنولوجي وتطبيقاتها قائمة على التعلم البنائي لتتمية مهارات التفكير المستقبلي

$$
\text { لتلاميذ الصف الثاني الإعدادي }
$$

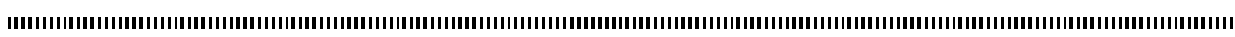

ء. تحديد فاعلية الوحدة المصممة في النانوتكنولوجي وتطبيقاتها قائمة على التعلم

البنائي لتنمية مهارات التفكير المستقبلي لتلاميذ الصف الثاني الإعدادي.

\section{أهمينة البحث:}

$$
\text { قد بُسهم هذا البحث في: }
$$

ا ـ تزوبد معلمي العلوم والموجهين وغيرهم بوحدة مصممة في النانوتكنولوجي وتطبيقاتها قائمة على التعلم البنائي، ومقياس لمهارات التفكير المستقبلي يمكن الاستعانة به لقياس هذا الغرض.

r. تقديم قائمة بتطبيقات النانوتكنولوجي في المجالات المختلفة إلى مصممي مناهج العلوم يمكن الاستعانة بهما في تطوير المناهج لتواكب التطورات الحديثة للعلوم وتطبيقاتها.

r. مساعدة تلاميذ المرحلة الإعدادية على تتمية مهارات التفكير المستقبلي لديهم.

\section{هدود البحث:}

$$
\text { اقتصر هذا البحث على الحدود الآتية : }
$$

ا . هوضومية: تصميم وحدة في النانوتكنولوجي وتطبيقاتها قائمة على التعلم البنائي لمنهج العلوم للصف الثاني الإعدادي، وقياس فاعليتها في تتمية مهارات التفكير المستقبلي لدى التلاميذ.

ץ. هكانية: مجموعة عشوائية من تلاميذ الصف الثاني الإعدادي بمدرسة الدسوقي

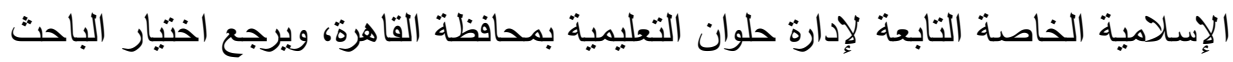

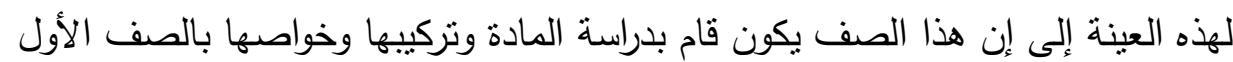

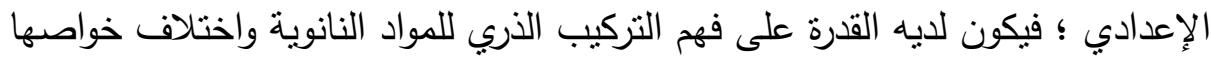

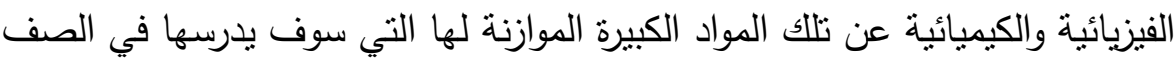
الثاني الإعدادي؛ مما يساعد على تتمية مهارات التفكير المستقبلي لديه. r. زهانية: تم إجراء هذا البحث في أثناء الفصل الدراسي الثاني من العام الدراسي $\cdot r^{r} \cdot 19 / 4 \cdot 11$

\section{هنهمج البحث:}

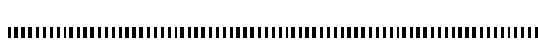

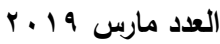

19

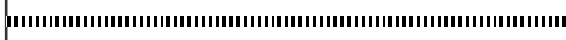
المجلد الخامس والعشرون 
تصميم وحدة في النانو تكنولوجي وتطبيقاتها قائمة على التعلم البنائي لتتمية مهارات التفكير المستقبلي

$$
\text { لتلاميذ الصف الثاني الإعدادي }
$$

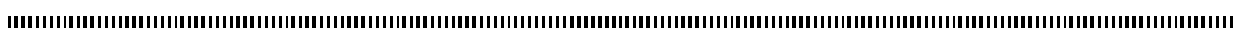

$$
\text { اتبع هذا البحث المنهجين الآتبين : }
$$

ا ـ المنهم الوصفي التصليلي: وذلك في الجزه الخاص بالفحص والدراسة النظرية للأدبيات التربوية والبحوث والدراسات السابقة التي تتاولت مجموعة المحاور العلمية التي يتضمنها البحث وأيضاً يتم إتباع هذا المنهج في أثتاء إعداد أدوات البحث وموات التهات المعالجة التجريبية.

r . المذهج شبه التجريبي: وذلك في الجزء الخاص بالجانب التطبيقي للبحث ، بهدف تعرف ما يحدثه التذخل التجريبي المتمثل في (وحدة مصدمة في النانوتكنولوجي وتطبيقاتها قائمة على التعلم البنائي) من تأثير في المتغيرات التابعة للبحث (مهارات التفكير المستقبلي) لتلامبذ الصف الثاني الإعدادي.

\section{التصميم التجريبي للبحث:}

اعتمد هذا البحث على استخدام التصميم التجريبي ذو المجموعة الوحدة: المجموعة التجريبية مع التطبيق القبلي والبعدي لأدوات البحث على المجموعة. وبذلك ستكون متغيرات البحث كالتالي:

ا ـ المتغير المستقل: الوحدة التعليمية المصممة في النانوتكنولوجي وتطبيقاتها القائمة على التعلم البنائي (إعداد الباحث). r. المتغير التابع: تتمية مهارات التفكير المستقبلي لتلاميذ الصف الثاني

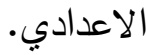

\section{إجراsات البحث:}

حيث تم استخدام منهجي البحث وفقاً للإجراءات الآتية:

\section{أولاً: إعداد الإطار النظري للبمث:}

وذلك من خلال الإطلاع على الأدبيات التربوية والبحوث والدراسات السابقة التي

$$
\text { تتاولت المحاور الأساسية للبحث وهي: }
$$

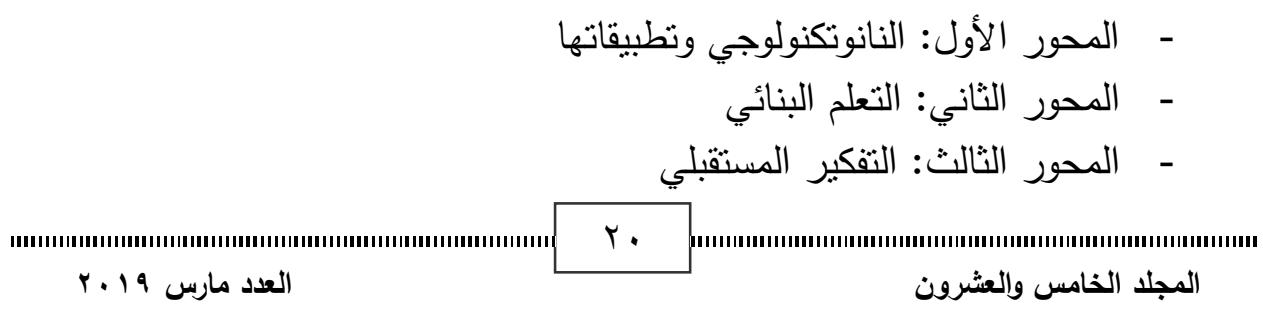


تصميم وحدة في النانو تكنولوجي وتطبيقاتها قائمة على التعلم البنائي لتتمية مهارات التفكير المستقبلي

$$
\text { لناميذ الصف الثاني الإعدادي }
$$

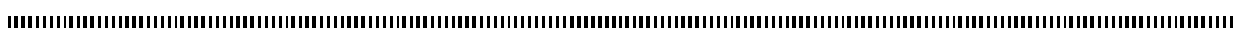

$$
\text { - المحور الرابع: سمات تلاميذ المرحلة الإعدادية }
$$

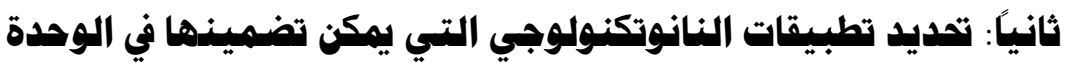

1. تحديد تطبيقات النانوتكنولوجي في المجالات المختلفة التي يمكن تدريسها

$$
\text { لتلاميذ الصف الثاني الإعدادي. }
$$

r ـ إعداد قائمة أولية بتطبيقات النانوتكنولوجي التي يمكن تضمينها في الوحدة من

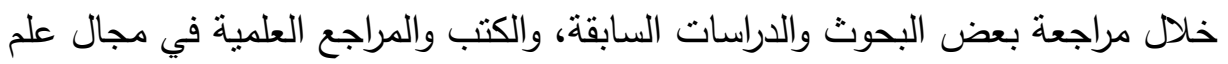
النانوتكنولوجي.

r. عرض القائمة الأولية على مجموعة من الخبراء وإجراء التعديلات المناسبة عليها. ع. التوصل إلى القائمة في صورتها النهائية.

ثالثً: إعداد هواد المعالجة التجريبية وأدوات البحث والتي شملت على: هواد المعالجة التجريبية (إعداد الوحدة في النانوتكنولوجي وتطبيقاتها قائمة

$$
\text { على التعلم البنائي): }
$$

وبناءً على ما سبق قام الباحث بتصميم وحدة "مازن في عالم النانوتكنولوجي"

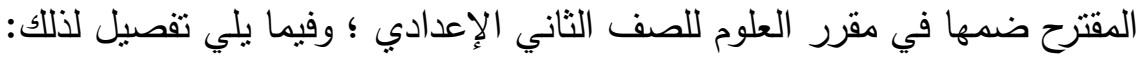

\section{• هفهم الوحدة الدراسية في النانوتكنولوجي:}

يُعرف الوحدة الدراسية في النانوتكنولوجي بأنها: "دراسة مخطط لهوئ لها مسبقاً ومجموعة

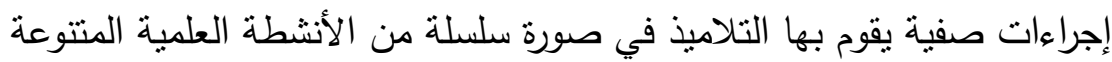

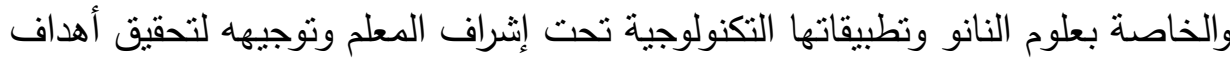

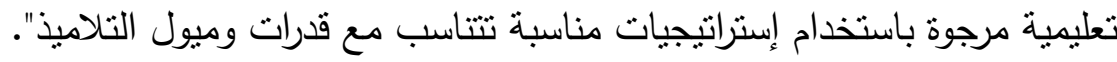

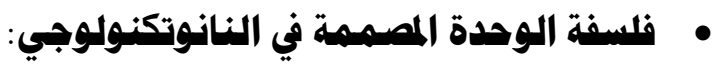

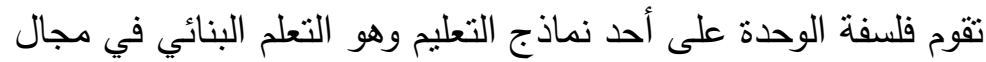

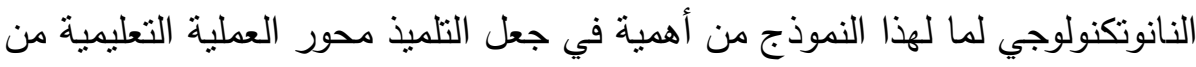


تصميم وحدة في النانو تكنولوجي وتطبيقاتها قائمة على التعلم البنائي لتتمية مهارات التفكير المستقبلي

$$
\text { لتلاميذ الصف الثاني الإعدادي }
$$

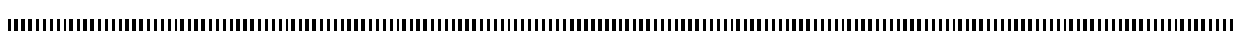

خلال تفعيل دوره، فالتلميذ يكتشف وبيحث عن المعارف النانوية وينفذ الأنشطة المختلفة في مجال النانو، ويربط بين العلم والتكنولوجيا، وبوفر للتلامبذ الفرصة لممارسة عمليات العلم الأساسية والمتكاملة؛ مدا يساعد على تتمية مهارات التفكير المستقبلي لديهم.

\section{• عناصر بناء الوحدة المسمهمة في النانوتكنهلوجي:}

\section{ه الأهداف المعاهة للاوحدة في ضوى التملم البنائي: تهدف هذه الوحدة إلى :}

ل مساعدة التناميذ على فهم بعض المفاهيم النانوية تنتاسب مع قدراتهم واستعداداتهم وتشبع حاجاتهم.

ل مساعدة التلامبذ على البحث والتقصي وجمع المعلومات من مصادر متعددة. ل تتمية مهارات التفكير المستقبلي التي تتمثل في مهارات التوقع الحدسي والتتبؤ العلمي والتصور المستقبلي مما تساعد التلاميذ على فهم وتفسير التطبيقات النانوتكنولوجي الحالية والمستقبلية.

لـتيع التلامبذ على المشاركة الإيجابية في جميع مواقف التعليم والتعلم في

$$
\text { إطار قائم على البحث والاستقصاء. }
$$

$\checkmark$ تقدير التلاميذ لدور العلماء في مجالات النانوتكنولوجي المختلفة باكتشاف واختراع الأجهزة النانوية التي تسهم في تحقيق رفاهية الإنسان وخدمة المجتمع.

\section{> الأهداف السلوكية للوحدة في ضوى التملم البنائي:}

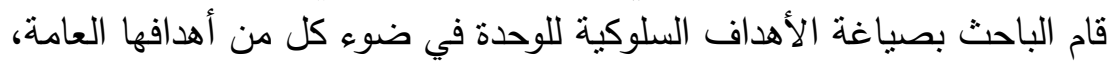
والموضوعات المقترحة للوحدة؛ لإن هذه الأهداف تساعد في تحديد إستراتيجيات التعليم ومصادر التعلم والأنشطة العلمية المناسبة، كما يتضح ذلك في دليل المعلم.

\section{> تمديد همتوى الوحدة في ضوs التعلم البنائي:}

يقصد بمحتوى الوحدة مجموعة المعارف والمهارات التي تشتمل عليها الوحدة والتي

تهدف إلى تحقيق أغراض معينة محددة على نحو مسبق (حمدي أبو الفتوح، ـ99 19.6

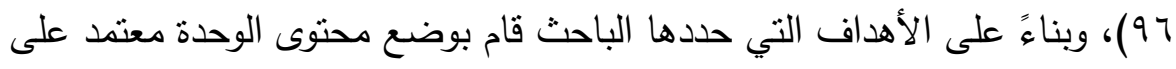

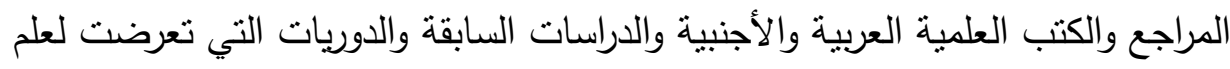

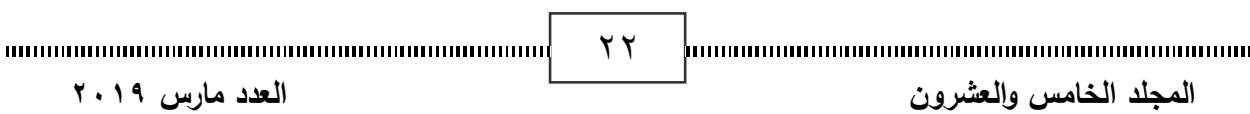


تصميم وحدة في النانو تكنولوجي وتطبيقاتها قائمة على التعلم البنائي لتتمية مهارات التفكير المستقبلي

$$
\text { لتلاميذ الصف الثاني الإعدادي }
$$

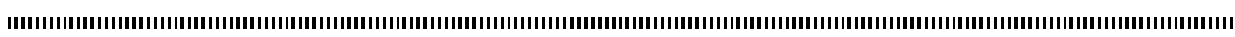

النانو والنانوتكنولوجي وتطبيقاتها، وعرض الباحث محتوى الوحدة في أربعة موضوعات كما هو مبين بجدول (1) التالي:

جدول (1) هوضوعات الوحدة المسمبمة في النانوتكنولوجي وتطبيقاتها

\begin{tabular}{|c|c|}
\hline الموضوع & 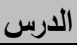 \\
\hline علم النانو & الأول \\
\hline المواد النانوية & الثاني \\
\hline تطبيقات النانوتكنولوجي من حولنا & الثالث \\
\hline النانوتكنولوجي والمستقبل & 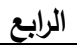 \\
\hline
\end{tabular}

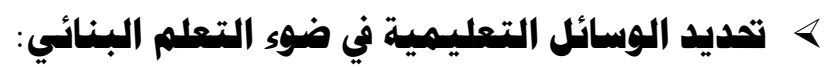

من الوسائل التي استخدمها الباحث في أثناء تدريس الوحدة:

السبورة الذكية - جهاز الحاسب الآلي (الكمبيوتر) - فيديوهات تعليمية منتوعة

متعلقة بموضوعات الوحدة - الرسوم والصور والمخططات المتعلقة بالمواد والأجهزة

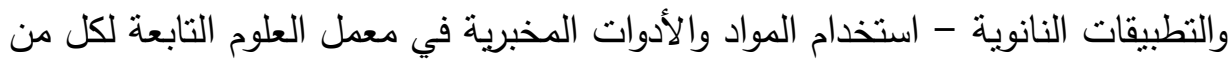
الأنشطة التعليمية لموضوعات الوحدة - خامات من البيئة لإجراء بعد التجارب العلمية منل (ترشيح الماء بألياف النانو).

\section{\& تهديد الأنشطة التعليمية في ضوء التعلم البنائي:}

حدد الباحث أهم الأنشطة التي تساعد على تتمية مهارات التفكير المستقبلي، وقيام

التلاميذ بها:

إجراء بعض التجارب العلمية في معمل العلوم مثل: تجربة تغير خواص المادة في

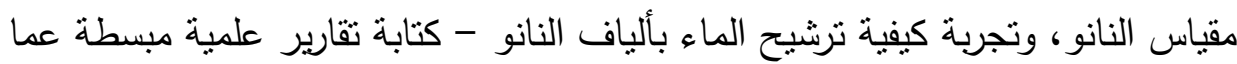
يقوم به التلاميذ من استقصاءات ومناقشتها - جمع مجموعة من الصور المرتبطة المواد والأجهزة النانوية - البحث في شبكة الإنترنت عن موضوعات متعلقة بتطبيقات النانوتكنولوجي المختلفة - كتابة سيناريوهات مستقبلية عن بعض الاكتشافات والتطبيقات النانوتكنولوجية في المجالات المختلفة - كتابة ابحاث عن مستقبل مصر والوطن العربي

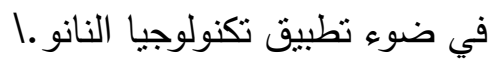

\section{> تمديد إستراتيجيات التعلم وطرق التدريس في ضوء التعلم البنائي:}

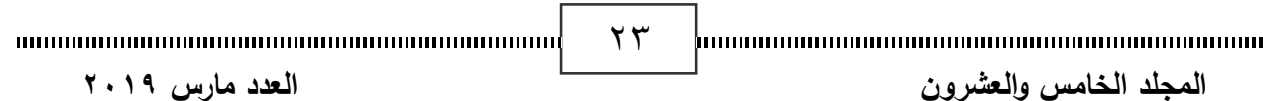


تصميم وحدة في النانو تكنولوجي وتطبيقاتها قائمة على التعلم البنائي لتتمية مهارات التفكير المستقبلي

$$
\text { لتلاميذ الصف الثاني الإعدادي }
$$

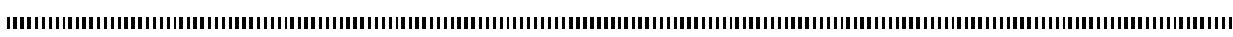

تم تدريس الوحدة باستخدام نموذج التعلم البنائي الذي يعتمد على إيجابية التلاميذ

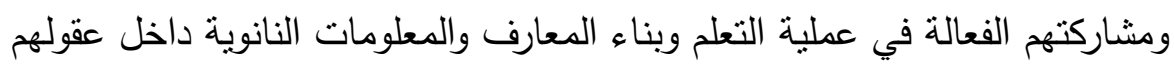

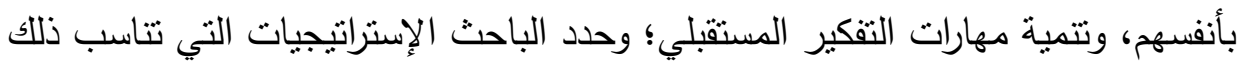
كما يلي:

إستراتيجية التعلم التعاوني Cooperative Learning - إستراتيجية التعلم

- Brain Storming إستراتيجية العصف الذهني Internet Learning إنترني

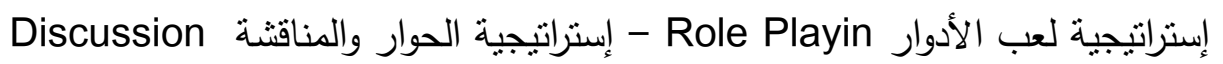

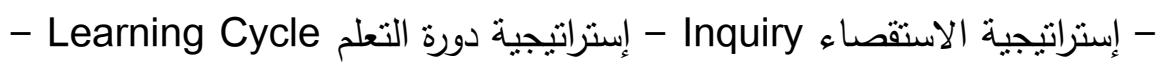
إستراتيجية حل المشكلات Problems Solving - إستراتيجية العروض العملية

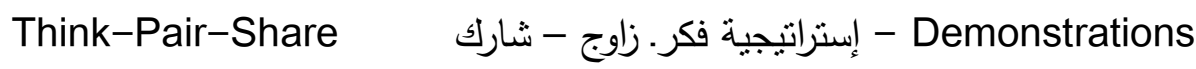

$$
\begin{aligned}
& \text { ه تهديد أساليب التقويم في ضوى التعلم البنائي: } \\
& \text { تم استخدام نوعين من أساليب التقويم هما: } \\
& \text { ا ـ التقويم التكويني: }
\end{aligned}
$$

قام الباحث بتقويم كل درس من موضوعات الوحدة المصممة وتشمل مجموعة من الأنشطة الصفية واللاصفية، حيث يمكن تتفيذ هذه الأنشطة بصورة فردية أو جماعية.

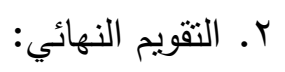

قام الباحث في نهاية تدريس الوحدة المصدمة بتطبيق مقياس مهارات التفكير

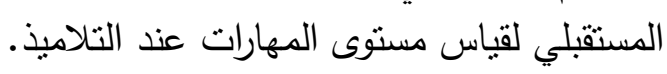

\section{> تهديد هدى صلاحية الوحدة وضبطها:}

للتأكد من السلامة العلمية وصدق محتوى الوحدة المصدمة في النانوتكنولوجي وتطبيقاتها لتلاميذ الصف الثاني الإعدادي ومعرفة صلاحيتها للتطبيق، تم عرض الوحدة في صورتها الأولية على مجموعة من الخبراء في مجالي العلوم والمناهج.

ب. دليل المعلم: لإيضاح كيفية تدريس موضوعات الوحدة، وبشتمل على: الأهداف

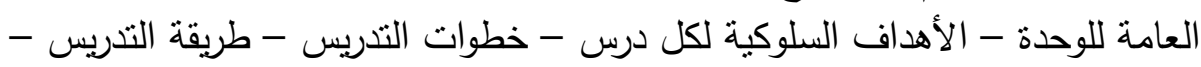
مصادر التعلم - الأنشطة التي تحقق من خلالها الأهداف - أوراق النشاط - المراجع التعان التي يمكن للمعلم أن يستعين بها في تدربس الوحدة.

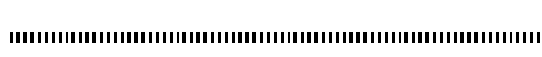

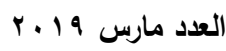

Y乏

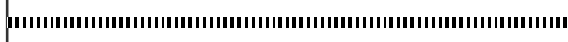
المجلد الخامس والعشرون 
تصميم وحدة في النانو تكنولوجي وتطبيقاتها قائمة على التعلم البنائي لتتمية مهارات التفكير المستقبلي

$$
\text { لتلاميذ الصف الثاني الإعدادي }
$$

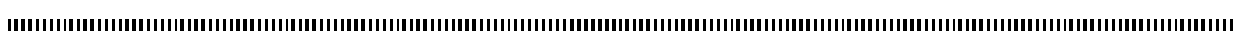

r. أدوات البحث (إعداد هقياس ههارات التفكيز المستقبلي هن قبل الباحث):

$$
\text { وقد اتبع الباحث الخطوات التالية لإعداد المقياس: }
$$

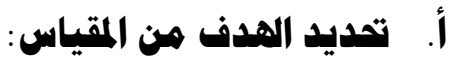

يهدف مقياس مهارات التفكير المستقبلي إلى قياس مستوى مهارات التفكير المستقبلي (التوقع الحسي، والتبؤ العلمي، والتصور المستقبلي)، وذلك لمعرفة فاعلية تدريس وحدة "مازن في عالم النانوتكنولوجي" لتمية مهارات التفكير المستقبلي لتلاميذ الصف الثاني الإعدادي.

\section{ب. تهديد المهارات التي يقيسها الاقيساس، وصياغة عباراته:}

عندما يتم تحليل ميدان القياس وتقسيمه إلى عناصره أو مواضعه، والكثف عن عند عدد

أجزاء كل موضوع والأهمية النسبية لكل جزء؛ فإنه يمكن بعد ذلك تحديد المهارات

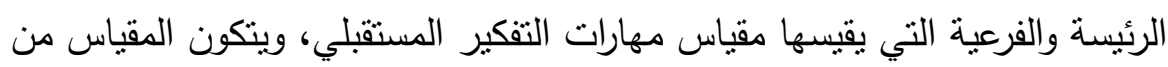
( • ( أسئلة يتعلق بمهارات التفكير المستقبلي؛ بحيث تخصص (0 درجات) لكل سؤال بمجموع ( · . 1 درجة) للمقياس ككل.

\section{ج. ضبط الاقياس وصدقه الظاهري:}

للتأكد من قياس كل سؤال للمهارة التي وضع لقياسها، تم عرض الصورة المبدئية لمقياس مهارات التفكير المستقبلي على مجموعة من الخبراء المتخصصين في مجال المناهج وطرق تدريس العلوم؛ لإبداء الرأي في أسئلة المقياس من حيث:

مدى ملائمة الأسئلة للمهارات التي تقيسها - الصحة العلمية واللغوية لمضمون الأسئلة - مدى مناسبة الأسئلة لمستوى التلامبذ - مدى وضوح تعليمات المقياس -

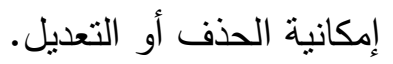

\section{د. تهديد صدق الاقيساس:}

لما كانت موضوعات الوحدة المصممة جديدة لم يسبق تعلُمها من قبل لتلاميذ الصف الثاني الإعدادي لزم أن تؤجل العمليات الإحصائية الخاصة بتحديد معاملات

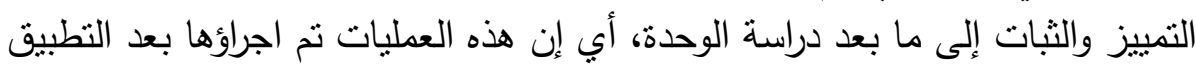
الفعلي للوحدة واستخدم الباحث البيانات التي تم الحصول عليها في التطبيق البعدي لتحديد هذه المعاملات، وقام الباحث بتحديد درجة ارتباط كل سؤال من أسئلة المقياس بالدرجة الكلية للمقياس، وذلك بإتباع الخطوات التالية: 
تصميم وحدة في النانو تكنولوجي وتطبيقاتها قائمة على التعلم البنائي لتتمية مهارات التفكير المستقبلي

$$
\text { لتلاميذ الصف الثاني الإعدادي }
$$

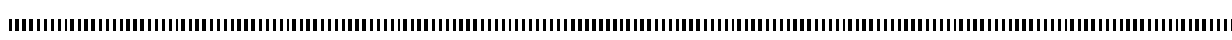

$$
\text { تم تصحيح جميع أوراق مقياس مهارات التفكير المستقبلي. }
$$

قـم الباحث هذه الأوراق إلى مجموعتين (مجموعة عليا، ومجموعة دنيا) على أساس الدرجة الكلية للمقياس.

تم بعد ذللك حساب معامل التمبيز لكل سؤال من أسئلة المقياس .

\section{هـ. تهديد ثبات الاقياس:}

قام الباحث بحساب ثبات المقياس بطريقة التجزئة النصفية Split-Half وهي إحدى طرق الاتساق الداخلي Internal Consistency، حيث يتم تقسيم أسئلة المقياس وفئة إلى نصفين منكافئين أو نصفين يضم أحدهما الأسئلة الفردية والتاني يضم الأسئلة الزوجية، وتستخدم درجات النصفين في حساب معامل الارتباط بينهما فينتج معامل ثبات نصف المقياس (را21/2)، ويلي ذللك استخدام معادلة سبيرمان - براون لحساب معامل ثبات

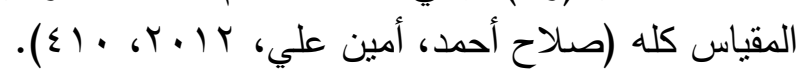

وبالتعوبض في معادلة (ر ا ) وجد إن قيمة معامل ثبات المقياس = V), • ، مما يؤكد ثبات المقياس.

\section{و. تحديد زمن المقيساس:}

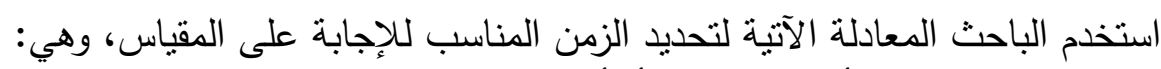
الزمن المناسب $=$ (7. ) (7قيقة.

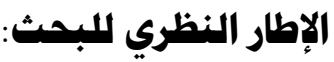

\section{المور الأول: النانوتكنولوجي وتطبيقاتها}

\section{I: مفهوم علم النانه Nano science}

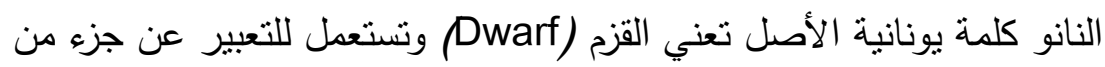
المليار من وحدة القياس في الرياضيات، ونانومنر هو جزء من المليار من المنز الواحد

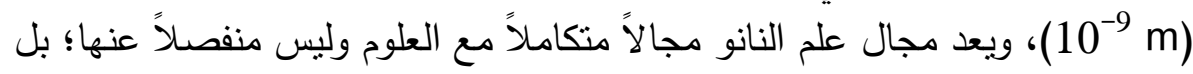
يعمل على المكونات الأساسية للمادة وهي الذرات والجزيئات، وقد نال علم النانو اهنماماً 
تصميم وحدة في النانو تكنولوجي وتطبيقاتها قائمة على التعلم البنائي لتتمية مهارات التفكير المستقبلي

$$
\text { لتلاميذ الصف الثاني الإعدادي }
$$

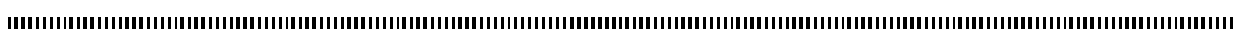
كبيراً على المستوى العالمي لما أحدثه من تغيرات جذربة في خواص المواد الفيزيائية والكيميائية والمغناطيسية والإلكترونية (Laherto,2010,160).

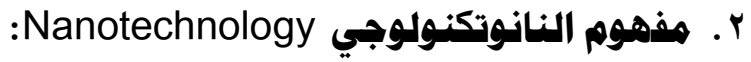

النانوتكنولوجي مصطلح مركب من كلمنين، الكلمة الأولى نانو Nano مهي بائة

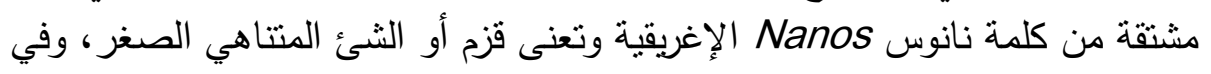
الرياضيات النانو يساوي جزء واحد من المليار ( ( . . . . . . . . . . . . من الإنة الوحدة المقاسة،

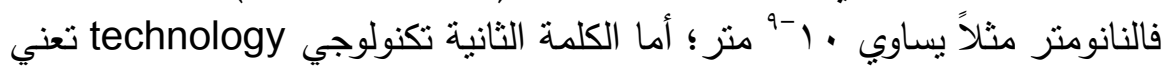
العملي للمعرفة في مجال معين، وبذللك يمكن القول بإن مصطلح النانوتكنولوجي والذي

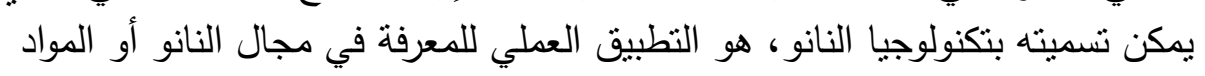

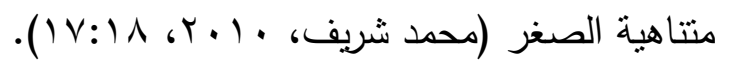

\section{r. Nanomaterial المواد النانوية}

يمكن تعريف المواد النانوية بأنها تلك الفئة المتميزة من المواد التي يمكن إنتاجها

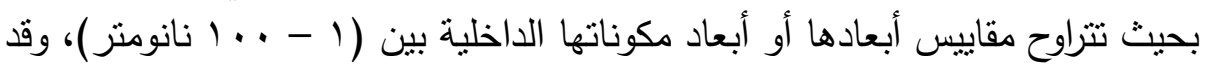

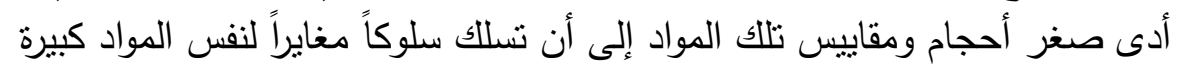
الحجم التي تزبد أبعادها عن . . 1 نانومتر ، وأن تتوافر بها صفات وخصائص شديدة

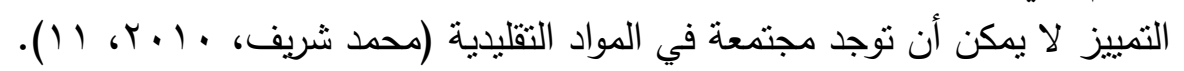

\section{ع. ـ خصائص المواد النانوية:}

تتغير خصائص المواد النانوية عند مستوى مقياس النانومتر حسب طبيعة

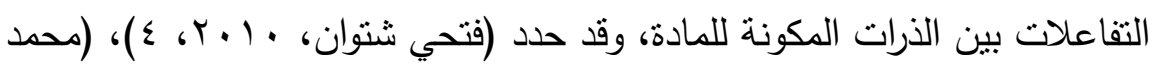

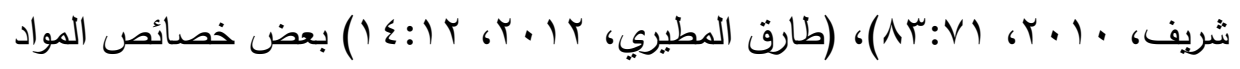

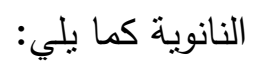

أ. الذصائص البصرية: عندما يتغير حجم جسميات المادة وأشكالها للحجم

النانوي؛ تختلف خصائصها البصرية وألوانها مثل جزئيات الذهب العادية ذات اللون الأصفر تظهر باللون الأحمر والأزرق والبنفسجي عند مقياس النانومتر .

ب. الفصائص الكهربائية: تمنلك المواد النانوية خصائص كهربائية فربدة من نوعها منل أنابيب الكربون النانوية، فالإكترونات يمكنها السير خلالها دون وجود أي الي

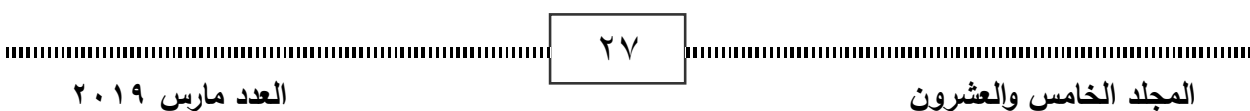


تصميم وحدة في النانو تكنولوجي وتطبيقاتها قائمة على التعلم البنائي لتتمية مهارات التفكير المستقبلي

$$
\text { لناميذ الصف الثاني الإعدادي }
$$

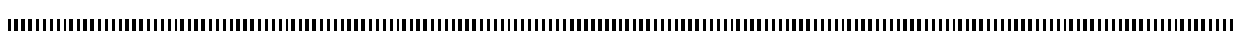
مقاومة حيث بتساوى عدد الإلكترونات الداخلة للأنبوب مع نلك الإلكترونات الخارجة

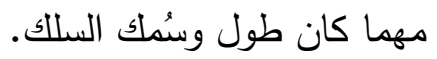

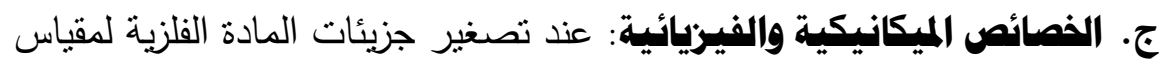
النانومتز ترتفع قيم درجة صلابتها، والتحكم في نرتيب ذراتها، مثل صلابة جسيمات

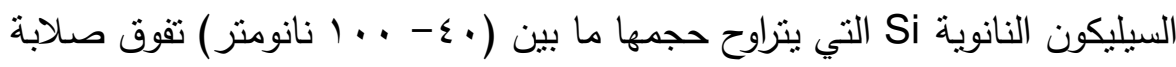

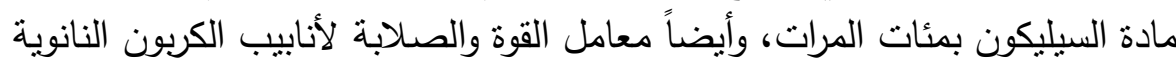

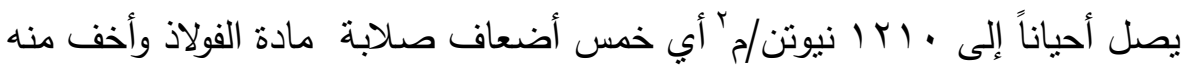
وزناً بحوالي ست مرات ثقريباً، وزيادة مرونتها نتيجة ازدياد طولها بالمقارنة مع قطرها. د. الفصائص المغناطيسية: تزداد مغناطيسية المواد عند تصغير جزبئاتها لمقياس النانومتر حيث تستخدم الحبييات النانوية فائقة المغناطيسية في صناعة أجهزة التحليل فائقة الدقة وأجهزة التصوبر بالرنين المغناطيسي.

\section{0. طرق تصنيع المواد النانوية:}

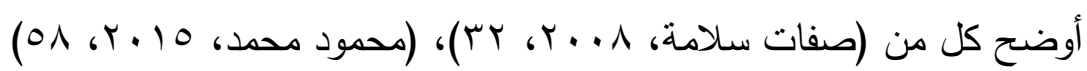

$$
\begin{aligned}
& \text { طريقتان لتصنيع المواد على مقياس النانومنر فيما يلي: } \\
& \text { الطريقة الأولى: هن القمة إلى الأسفل (Top-Down) }
\end{aligned}
$$

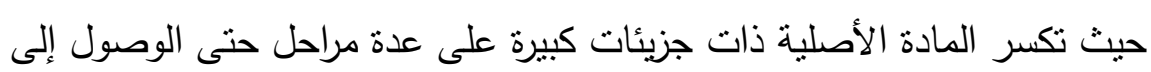

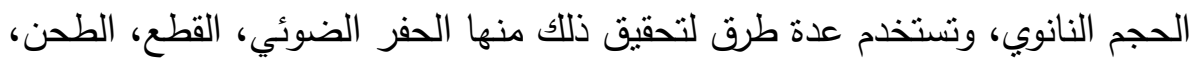
والتقتيت.

\section{الطريقة الثانية: من الأسفل إلى الأملى (Bottom-Up)}

هي عكس الطريقة الأولى حيث نُبنى المواد النانوية بداً من ترنيب ذرات وجزيئات للوصول إلى الثكل والحجم النانوي المطلوب، وتتم غالباً هذه الطريقة بطرق كيميائية تتميز بصغر حجم المواد المنتجة وقلة الفاقد والحصول على روابط قوبة للمواد النانوبة.

\section{1. تصنيف المواد النانوية:}

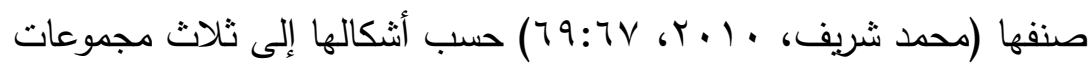
رئيسة:

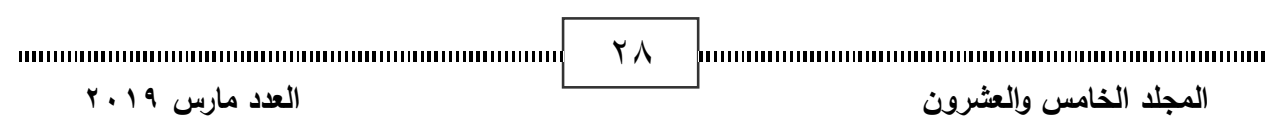


تصميم وحدة في النانو تكنولوجي وتطبيقاتها قائمة على التعلم البنائي لتتمية مهارات التفكير المستقبلي

$$
\text { لتلاميذ الصف الثاني الإعدادي }
$$

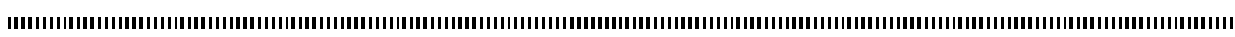

\section{أ. . هماد أحادية البدعد النانوي:}

هي مواد ذات بعد نانوي واحد فقط يتراوح ما بين (1 - . . 1 ) نانومتر ، مثل مرشحات النانو وألياف النانو وأسلاك النانو والأغشية الرقيقة.

\section{ب. هماد ثنائية الأبعاد النانوية:}

هي مواد يتراوح فيها مقياس بعدين من أبعادها ما بين (1 - . . . 1) نانومتر، منل أنابيب الكربون النانوية.

\section{أ. أ. مهواد ثلاثية الأبعاد النانوية:}

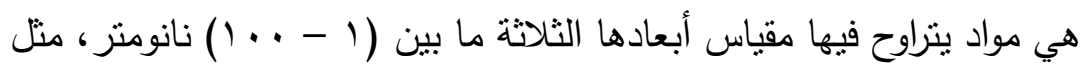
الحبيبات النانوية و صدفة النانو والجسيمات النانوية وكرات البوكي

V. بعض تطبيقات الناتوتكنولوجي التي يمكن تضمينها بالوحدة المصممة للصف

الثاني الإعدادي:

ب. تطبيقات النانوتكندولوجي في همال الطب كما أوضمها ( هممد شريف،

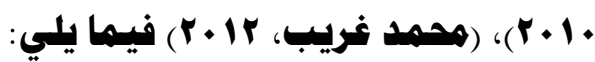
• تستخدم الأغلفة النانوية المطلية بالذهب لتدمير الخاليا السرطانية تستخدم الأسلاك النانوبة كمجسات حيوية نانوية وذلك لحساسيتها العالية وحجمها الصغير جداً، ويمكن استخدام هذا المجس الحيوي النانوي في اكتشاف عدد كبير من الأمراض في مراحلها الأولية.

تصنيع مجسات عضوية منتاهية الصغر تستشعر حدوث أي انخفاض حاد في مستوى نسبة الجلوكوز في الدم.

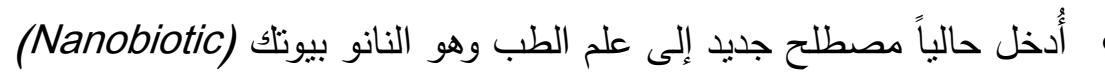

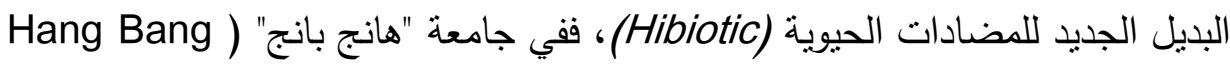
(University المعروف إن الفضة قادرة على قتل ـ7 جرثومة ميكروبية دون أن تؤذي جسم الإنسان. انتاج دعامات نانوية خاصة بتوسيع الثرايين مصنوعة من سبائك التيتانيوم 
تصميم وحدة في النانو تكنولوجي وتطبيقاتها قائمة على التعلم البنائي لتتمية مهارات التفكير المستقبلي

$$
\text { لتلاميذ الصف الثاني الإعدادي }
$$

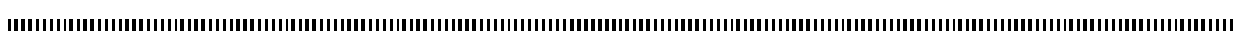

• تدخل في مجال زرع وتجديد الأنسجة وذللك من خلال استخدام البروتينات ذاتية

التجميع في تجديد الأنسجة، أما في مجال العظام تدخل تكنولوجيا النانو في استبدال

المفاصل وتضميد الجروح.

\section{ب. تطبيقات النانوتكنولوجي في هجال الصناعة كما أوضهها (أحمد حجازي،}

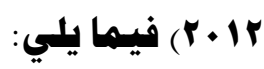

تقدم تقنية النانو الكثير لتحسين صناعة الطائرات والسيارات؛ فهي تذخل في

صناعة الأبواب والمقاعد والدعامات حيث نتميز القطع المحسنة بالنانو أنها صلبة وذات

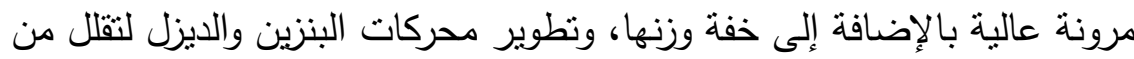
استهلاك الوقود، كما أنها تساعد في صنع محركات نفاثة تتميز بهدوئها وأدائها العالي.

• تخخل تقنية النانو في تحسين صناعة الزجاج بشكل عام وتحسين زجاج النوافذ

بشكل خاص حيث يصبح عالي الثفافية وذللك باستخدام نوع معين من جسيمات النانو في صناعة الزجاج يُعرف بـ "الزجاج النشط" حيث إن هذه الجسيمات تتفاعل مع الأشعة فوق البنفسجة مما يزيل الرواسب والأوساخ والغبار الملتصق بالزجاج وتتميز بأنها تشكل

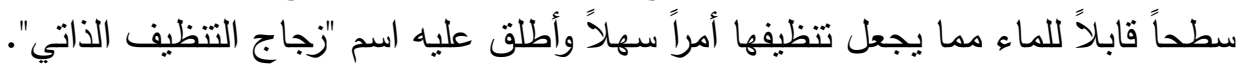
• تم تحسين صناعة بعض المنتجات الرياضية مثل: مضارب الهوكي، ومضارب البيسبول، ومضارب وكرات التس، وكرات الغولف باستخدام تقنية النانو لتقويتها وإكسابها المرونة والخفة.

صناعة دهانات وصبغات نانوبة لها القدرة على مقاومة الخدش والتآكل؛ مما

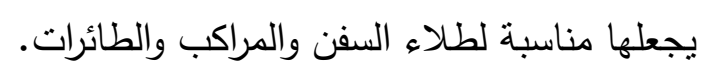

ج. تطبيقات النانوتكنهاوجي في همال الزراعة والغذاء كما أوضمها (هممد

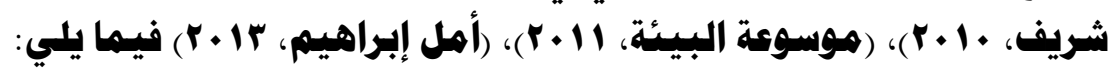

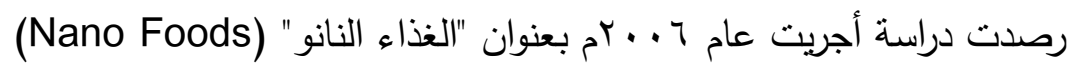

بعض تطبيقات النانوتكنولوجي في مجال الأغذية ومنها كبسولات (Nano Capsules)

لتنشيط تلك الأغذية واستبدال كوليسترول اللحوم، وأنابيب النانو (Nano Tubes) وجسيمات نانو (Nano Particles) لإزالة المسببات المرضية وإنتاج الأغلفة المقاومة وغيرها.

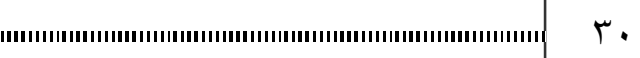

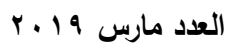

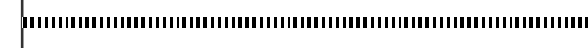
المجلا الخامس والعشرون 
تصميم وحدة في النانو تكنولوجي وتطبيقاتها قائمة على التعلم البنائي لتتمية مهارات التفكير المستقبلي

$$
\text { لتلاميذ الصف الثاني الإعدادي }
$$

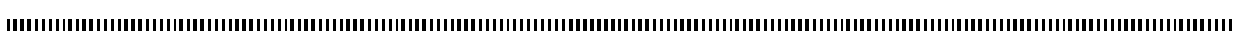

$$
\text { إيجاد أغلفة مزودة بجزيئات النانو لا تزبد سمكها عن (0 نانومتز) مضادة }
$$

للميكروبات والفطريات من معادن الفضة والماغنسيوم والزنك حيث أنها أغلفة أخف وزنأ وأكثر متانة وأكثر مقاومة للحرارة وتم أيضاً دمج حبيبات وأنابيب النانو التي تعمل على منى ونى غلق مسامها بهدف منع وصول الرطوبة للغذاء الطازج. إنتاج مجسات وأنظمة ذكية للكثف عن الملوثات الغذائية وتعرف البكتيربا في لرطي

المواد الغذائية.

تحسين جودة المواد الغذائية وخفض محتواها الضار من خلال التحكم في بنية

$$
\text { وتركيب مكوناتها الأساسية. }
$$

إنتاج مبيدات حشرية يتم رشها على النبات تتميز بلونها الثفاف الذي يمكنها

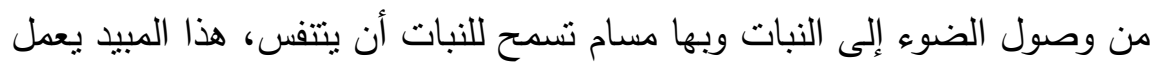
كطبقة من الزجاج على النبات فلا تستطيع الحشرات أن تخترقه للوصول إلى النبات. تصنيع حبيبات كيميائية زراعية تستخدم في مكافحة الحشرات والفطريات والآفات الزراعية التي تصيب التربة والنباتات والبذور، والتي تتميز بارتفاع قيمة مساحة سطحها، مما يعني نرشيد استخدامها وتخفيض الكميات المستخدمة منها.

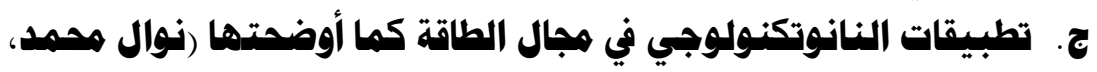

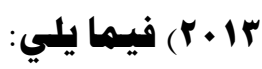
إنتاج الخلايا الشمسية وخلايا الوقود الهيدروجينية تتميز بتكلفة قليلة وكفاءة عالية. عمل خلايا إلكتروشمسية تصنع من جزبئات السيليكون النانوية حيث يتم من خلالها تحويل أثعة الثمس مباشرة إلى كهرباء. عمل بطاريات عالية الجودة وتعمل لفترات أطول.

\section{د. تطبيقات النانهوتكنولوجي في همال السلع الاستهلاكية كما أوضمتها

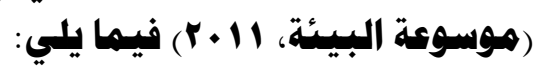
إنتاج مواد مصنعة دن الجزبئات النانوية تبقى أسطح الأرضيات لامعة. عمل مركبات تدخل في العمليات الحيوية عند تتشيطها بالضوء، وجزيئات نانوية غير مرئية تكسب الزجاج خاصية التظيف التلقائي. 
تصميم وحدة في النانو تكنولوجي وتطبيقاتها قائمة على التعلم البنائي لتتمية مهارات التفكير المستقبلي

$$
\text { لناميذ الصف الثاني الإعدادي }
$$

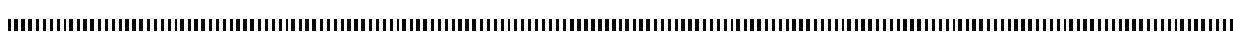

تصنيع مواد نانوية من أكسبد الزنلك لتنقية الأشعة فوق البنفسجية بهدف تحسين

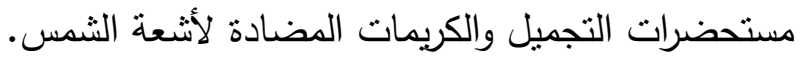

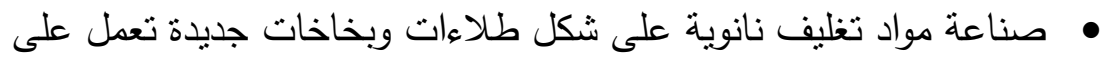

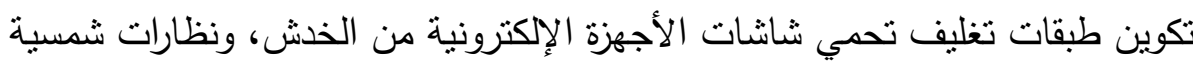

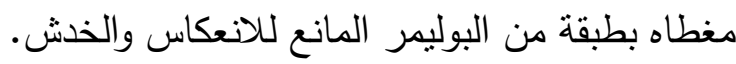

• إنتاج ملابس ذات أنسجة نانوية لها خاصية التظظيف الذاتي دون الحاجة

لغسالة.

\section{ه. تطبيقات النـانوركنهولوجي في همال البيئة كما أوضمها (هممد شريف،}

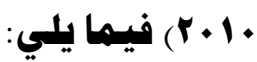

معالجة التربة والمياه الجوفية الملوثة، وتخفيض معدلات استهلاك المواد الخادم

من خلال ادخال التحسينات في الصناعات التحويلية القائمة على النانوتكنولوجي.

تحلية الماء بواسطة ألياف النانو وذلك باستخدام كواثف ذات حساسية عالية

تسمى بكواشف النانو حيث تستطيع اكتشاف أي تلوث في الماء والهواء حتى لو كان بتركيز ضئيل.

إزالة العناصر الخطيرة من النفايات الصناعية مثل استخدام الفضة النانوبة في

إزالة القمامة من المياه عن طريق تسليط مجال مغناطيسي عليها.

\section{و. تطبـةات النانوتكنولوجي في همال الإلكتزونيات ووسائل الاتصال كما}

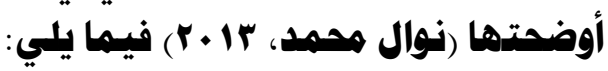

• صناعة إلكترونية مرنة من بلورات الكادميوم النانوبة، ودوائر متكاملة تحتوي

على السليكون النانوي أو الأنابيب النانوبة تتميز بسرعة أكبر في نقل البيانات بين الدوائر المتكاملة.

استخدام المغناطيسات النانوية كمفاتيح مثل الترانزستور في الدوائر الكهربية التي تستهلك أقل قدر من الطاقة.

تصنيع الأسلاك النانوية من أثباه الموصلات في إنتاج أجهزة كمبيوتر صغيرة الحجم وذو ذاكرة عالية.

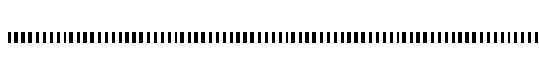

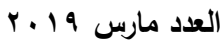

rr | المجلد الخامس والعشرون 
تصميم وحدة في النانو تكنولوجي وتطبيقاتها قائمة على التعلم البنائي لتتمية مهارات التفكير المستقبلي

$$
\text { لتلاميذ الصف الثاني الإعدادي }
$$

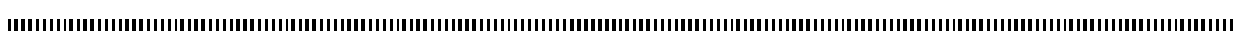

إنتاج أجهزة نانو لاسيلكية، وأجهزة تخزين الملفات الصوتية والمرئية، والهواتف

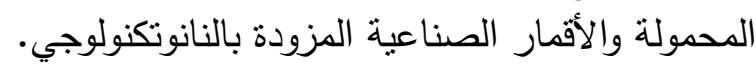

ز. تطبيقات النانوركنهلوجي في المجال العسكري:

• تطوير أزياء ومعدات وأسلحة عسكرية وأجهزة مجال التجسس والكثف عن التن

المتفجرات وإبطال مفعولها.

صناعة طلاعات نانوية للطائرات المضادة للردار •

\section{تطبيةقات النانوتكنولوجي في همال الفضضاء:}

تصنيع سفن الفضاء من أنابيب الكربون النانوية خفيفة الوزن، وعمل وعل أسلاكك وكابلات مصاعد الفضاء مما يقل التكاليف الخاصة بتوصبل المواد للمدارات.

صناعة بدل رواد الفضاء المزودة بروبوتات النانو الحيوية التي تشاعد رائد

الفضاء في حل المشاكلات التي تقابله مثل توصيل الأدوية أو في حالات الطوارئ الطبية.

\section{المهور الثاني: التهمثم البنائي}

\section{أ. هفهوم نموذج التعلم البنـائي:}

وعرف (حمدي عبدالعظيم، ( . . ، 9) نموذج التعلم البنائي بأنه: "تصور يتم تتفيذه لمساعدة التلامبذ على بناء مفاهيمهم ومعارفهم العلمية وفق أربع مراحل متتابعة مقتبسة في أصلها من مراحل دورة التعلم الثلاث وهذه المراحل هي: مرحلة الدعوة،

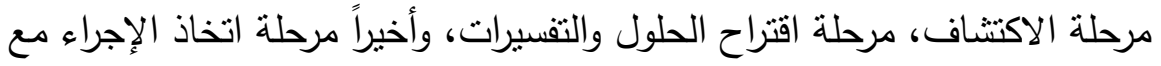
التأكيد على ربط العلم بالتكنولوجيا والمجتمع خلال المراحل الأربع".

\section{ا. الأسس والمبادئ العامة التي يرتكز عليدها نموذج التعايم البنائي:}

Perkins, ) يعتمد هذا النموذج على أسس ومبادئ قوبة كما أوردها كل من بيركنزي

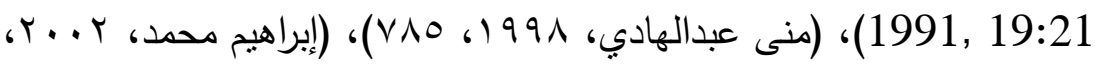

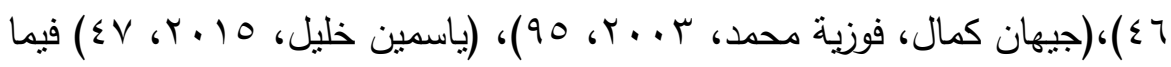
بلي : 
تصميم وحدة في النانو تكنولوجي وتطبيقاتها قائمة على التعلم البنائي لتتمية مهارات التفكير المستقبلي

$$
\text { لتلاميذ الصف الثاني الإعدادي }
$$

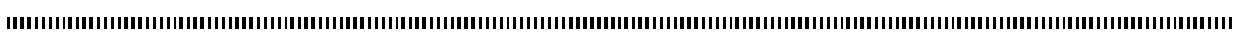

أ. إعداد الدعوة لمشاركة المتعلمين بصورة فعالة في بداية خطوات التعلم الجديد؛

حيث يقوم المتعلمون بتحديد الظواهر العلمية والتعبير عنها بصورة لفظية، ويقومون بهن

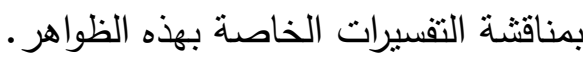

ب. استخدام تصورات ومفاهيم المتعلمين وأفكارهم في توجيه وقيادة الدرس، وإتاحة

$$
\text { الفرصة لاختبار أفكارهم وإن كانت خاطئة. }
$$

ج. إتاحة الفرصة للتلاميذ لمناقشة ما تم جمعه من خلال عمل حوار بين المتعلمين أنفسهم أو بين المتعلمين والمعلم.

د. تشجيع المتعلمين على تحسين وتعديل تفسيراتهم، وعدم الحكم على صحة

$$
\text { التفسيرات أو خطأها. }
$$

هـ الإصرار على سماع تتبؤات المتعلمين للنتائج قبل إجراء التجارب والاختبارات العلمية المتتوعة.

و . الانتباه لمفاهيم المتعلمين البديلة، ومعالجتها من خلال تصميم الدروس بشكل

$$
\text { يتحدى تصوراتهم الخاطئة. }
$$

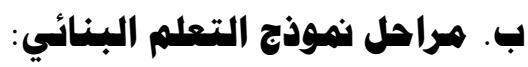

\section{ع. تهرحلة الدعوة:}

يتم في هذه المرحلة دعوة التلاميذ إلى التعلم؛ حيث يقوم المعلم بجذب انتباه واسنتارة دافعية التلامبذ إلى موضوع الدرس الجديد أو مشكلة معينة المطلوب الوصول لحلها في

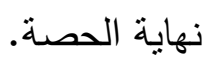

\section{د. هرحلة الاكتشاف والابتكار:}

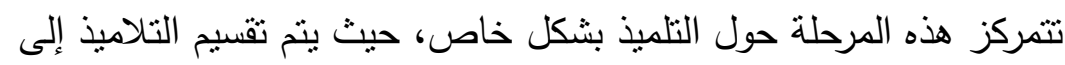

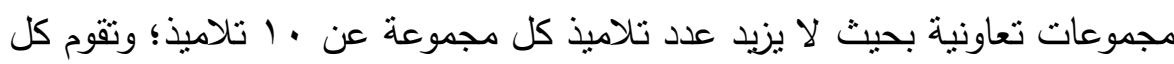
مجموعة بمناقنتة ما يقدم لهم ومن خلال إجراء الأنشطة والمواقف التعليمية، والمعلم يقوم بتشجيع التلاميذ وحثهم على التعاون وتبادل الآراء وتعزيزهم.

\section{ه. هرحلة اقتراح الصلول والتفسيرات:}

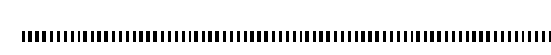

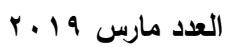

rะ |1' المجلا الخامس والعشرون 
تصميم وحدة في النانو تكنولوجي وتطبيقاتها قائمة على التعلم البنائي لتتمية مهارات التفكير المستقبلي

$$
\text { لناميذ الصف الثاني الإعدادي }
$$

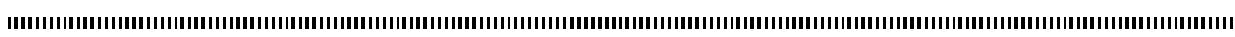

في هذه المرحلة يقوم المعلم بعمل جلسة حوارية عامة وتتظيم المناقثات وتوجيه الأفكار والحلول بينه وبين التلاميذ؛ حيث ثقوم كل مجموعة بتقديم ما توصلت إلبه من بن حلول واستتناجات وتقسيرات للأسئلة المطروحة عليها.

\section{و. هرحلة اتخاذ الإجراء والتطبيبق:}

تهدف هذه المرحلة إلى توسيع وتعميق تعلم التلاميذ للأفكار والمفاهيم والمعارف

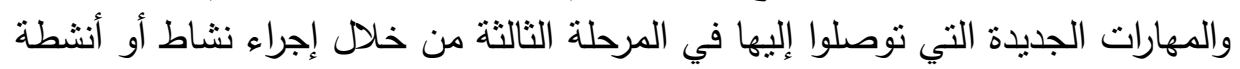
ذات علاقة بالموضوع أو المشكلة المطروحة.

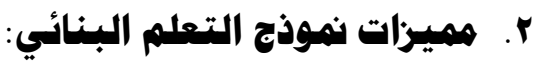

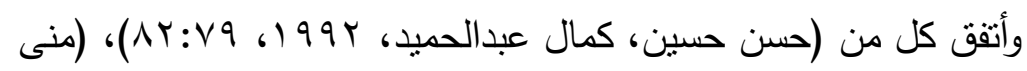

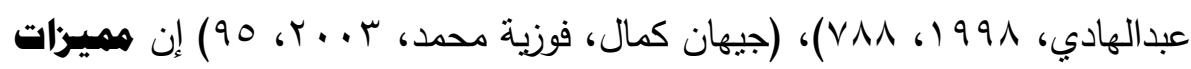
نهموذج التملهم البناءي على النصو التالي:

أ. يجعل المتعلم محور العملية التعليمية، فهو يبحث ويتقصى لكي يصل إلى هلى المفاهيم والمعارف بنفسه.

ب. يتيح الفرصة للمتعلمين للتفاعل الإيجابي مع قضايا ومشكلات المجتمع الذي يعيش فيه.

ج. يتيح الفرصة أمام المتعلمين لممارسة عمليات العلم المختلفة مثل: الملاحظة والاستتاج وفرض الفروض واختبار صحتها وغيرها من عمليات العلم.

د. يتم التعلم من خلاله في جو ديمقراطي يتيح الفرصة للتفاعل النشط بين التلامبذ

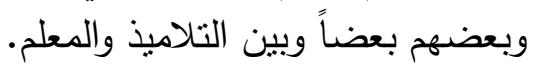

هـ ـ يربط النموذج بين العلم والتكنولوجيا؛ مما يوضح الروئية أمام المتعلمين إلى دور العلم في حل مشكلات المجتمع. يرنط لين

\section{r. العلاقة بين انموذج التعلم البنائي والنانموتكنولوجي وتطبيقاتها:}

قد اختار الباحث نموذج التعلم البنائي في تدريس وإعداد وحدة النانوتكنولوجي وتطبيقاتها لتتمية مهارات التفكير المستقبلي لتلامبذ الصف الثاني الإعدادي بوجه خاص؛ نظراً لما درسه التلاميذ في مادة العلوم بالصف الأول الإعدادي منل: المادة

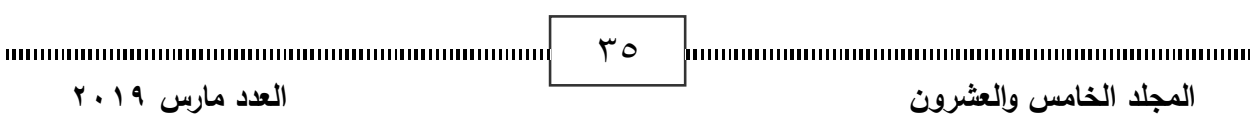


تصميم وحدة في النانو تكنولوجي وتطبيقاتها قائمة على التعلم البنائي لتتمية مهارات التفكير المستقبلي

$$
\text { لناميذ الصف الثاني الإعدادي }
$$

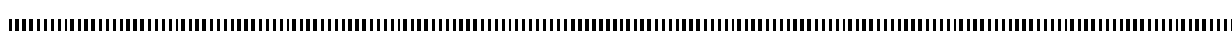

وتركيبها الذري، وخواصها الكيميائية والفيزيائية، وتصنيف العناصر والمركبات الكيميائية،

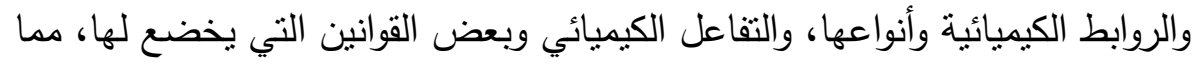
يساعد التلميذ على تعلم النانوتكنولوجي وبناء المفاهيم والمعارف الخاصة بها داخل وبله عقله

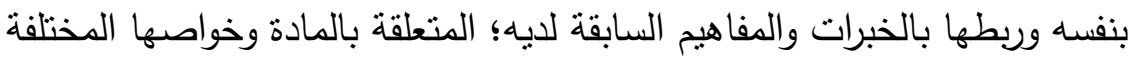
وتركيبها الذري؛ ويكون لديه القدرة على التمييز بين خواص المادة في حجمها العادي بهاي

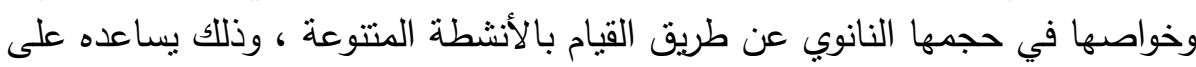
استخدام النانوتكنولوجي والمواد النانوبة في المجالات المختلفة سواء كانت طبية، صناعية، زراعية، بيئية أو في حياته الشخصية.

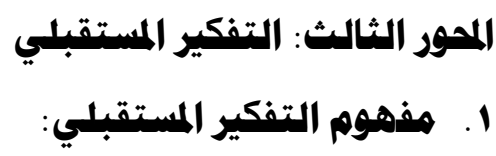

القدرة على صياغة فرضيات جديدة، والتوصل إلى ارتباطات جديدة باستخدام المعلومات المتوفرة، والبحث عن حلول جديدة، وتعديل الفرضيات، وإعادة صياغتها عند

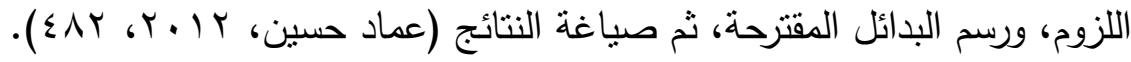
وبعرفه "بنتلي" (Bentley, 2004) على أنه نوع التقكير الذي تستخدم خلاله السيناريوهات التي تعطينا تصوراً لفترة عشرين أو ثلاثين سنة في المستقبل.

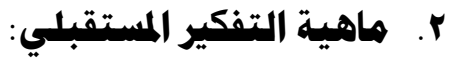

يمكن تحديد ماهية التفكير المستقبلي في عدة عمليات:

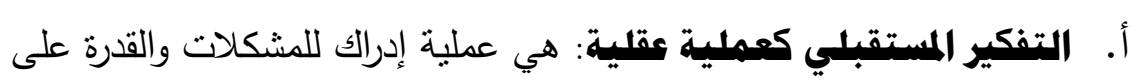
صياغة فرضيات جديدة، والتوصل إلى ارتباطات جديدة باستخدام المعلومات المتوفرة،

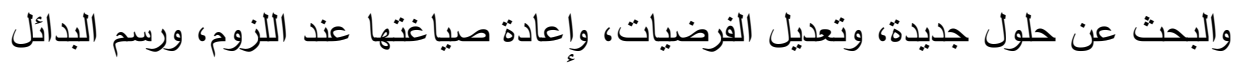
المقترحة، ثم صباغة النتائج. ب. التفكير المستقبلي كمهملية تصور: هي عملية توليد الكثير من الأفكار، وإثارة

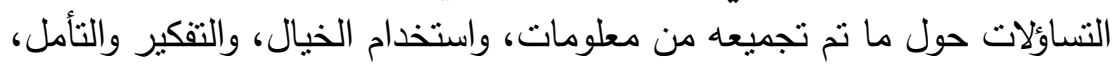

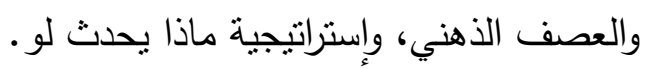

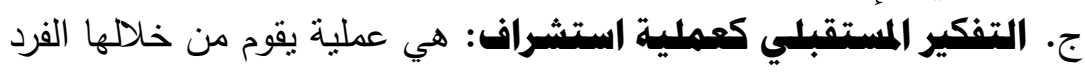

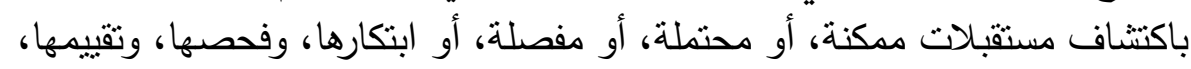
واقتراحها، ويتم صياغة ذلك على شكل ثتبؤات مستقبلية. 
تصميم وحدة في النانو تكنولوجي وتطبيقاتها قائمة على التعلم البنائي لتتمية مهارات التفكير المستقبلي

$$
\text { لناميذ الصف الثاني الإعدادي }
$$

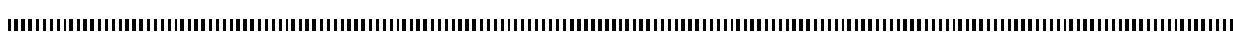

د. التفكير المستقبلي كعملية تنبوة: هي عملية يتم من خلالها محاولة تكوين

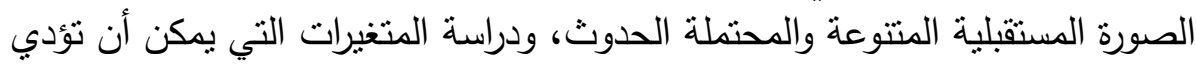
إلى احتمال وقوع هذه الصورة المستقبلية.

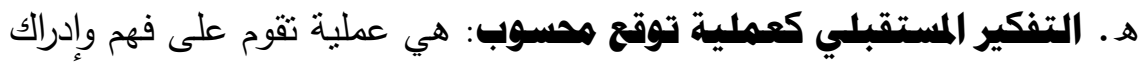

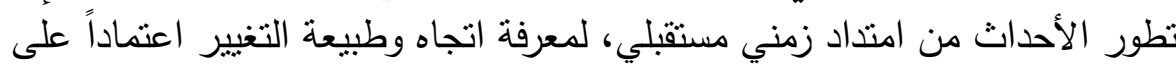
استخدام معلومات متتوعة عن الحاضر وتحليلها، والاستفادة منها لرسم الصورة المستقبلية المفضلة والمرجوة.

و. التفكير المستقبلي كمماية هل للامشكلات: هي عملية يتم من خلالها رصد وتتبع مسار المشكلات الحاضرة، واقتراح بدائل متعددة لما ستكون عليه المشكلة في منيه

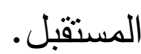

ز · التفكيز الماتقبلي كمملية إنتاجية إبداعية: هي عملية بتم من خلالها

تحرير الفرد نسبياً من قيود الحاضر ، متمثلة في النظرة قصيرة الأمد التي تغذى بها المصالح الضيقة، والتي تشكل عقبة في سبيل إنتاج شئ جديد، والخروج بمخزون معلوماتي يمكن الانتفاع به مستقبلاً.

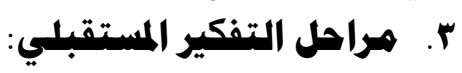

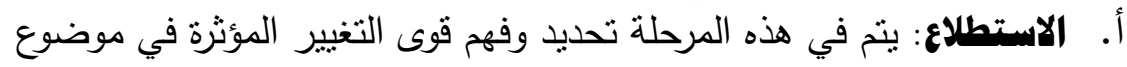
الدراسة أو البحث أو المشكلة.

ب. التطلع للأهمام: يتم في هذه المرحلة توضيح المؤثرات التغييرية في تشكيل

المستقبل، وذلك من أجل وصف القصص المستقبلية الممكنة، والهامة والمفضلة. ج. التخطيط: يتم في هذه المرحلة عمل تخطيط استراتيجي من أجل قيادة التغير ، والعمل على تخطي الفجوة بين الواقع الحالي والمستقبل المأمول في محاولة لرسم صورة المستقبل المفضل والممكن.

د. التنفيذ: يتم في هذه المرحلة تطبيق الإستراتيجيات المتوقعة مع متابعة

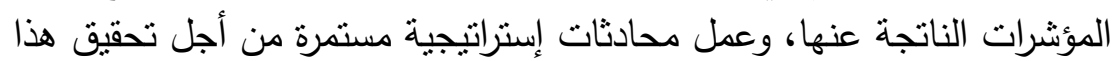

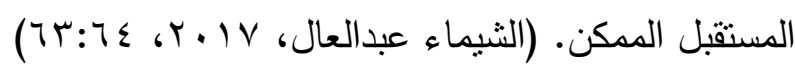

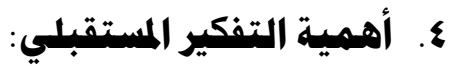

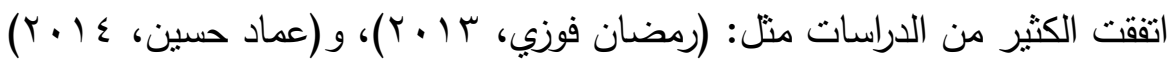

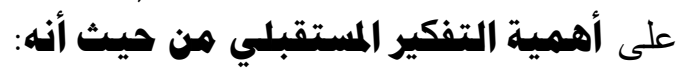

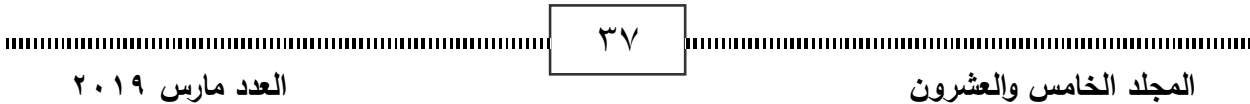


تصميم وحدة في النانو تكنولوجي وتطبيقاتها قائمة على التعلم البنائي لتتمية مهارات التفكير المستقبلي

$$
\text { لتلاميذ الصف الثاني الإعدادي }
$$

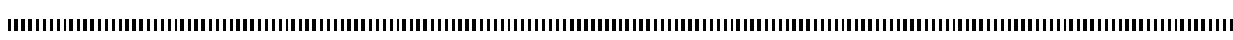

$$
\begin{aligned}
& \text { أ. الخطوة الأولى للمشاركة الإيجابية في صنع المستقبل. } \\
& \text { ب. يوفر قاعدة معرفية حول البدائل المستقبلية. }
\end{aligned}
$$

ج. بياعد في اكتشاف المشكلات المستقبلية قبل حوفيل حدوثها. د. يساعد في زيادة الثقة بالنفس لمواجهة المستقبل وما به من مشكلات مطروحة. هـ البحث عن حلول مستقبلية لحل المشكلات المعاصرة.

$$
\text { و. . تطوير مستوى الحدس والتوقع. }
$$

إن مهارات التفكير المستقبلي لا يمكن تعلمها بصورة مباشرة، ولكن يتم تعلمها عن

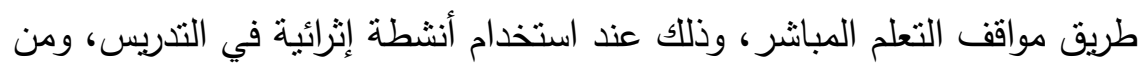
مهارات التفكير المستقبلي التي حددها الباحث لتنميتها لتلاميذ الصف الثاني الإعدادي:

\section{أ. ـهارة التوقع المدسي:}

عرف (محمد بخيت، ب ا • r) مهارة التوقع على أنها "العملية التي يتم من خلالها

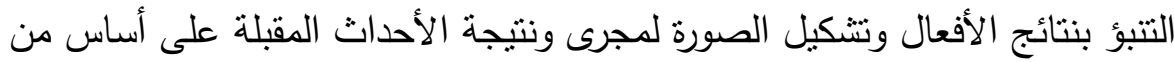

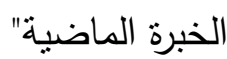

وعرف كل من (محمد قاسم، محمد أبو راسين، 0 . . Y) الحدس على أنه "طريقة

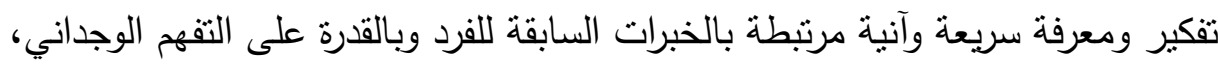

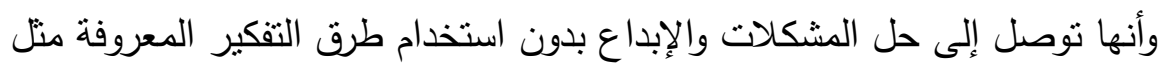

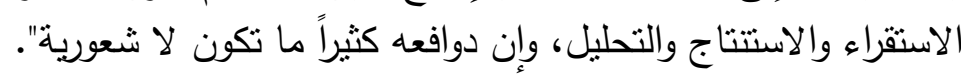
ومن المهارات القرعية لمهارة التوقع الحدسي مهارتي: دوانهي:

• التفهم الوجداني: هي قدرة التلميذ على الإدراك بحساسية، وأن يضع نفسه

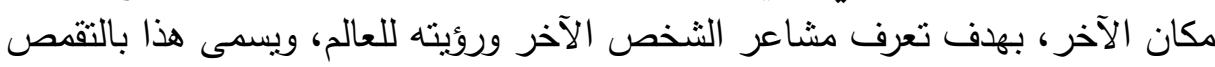

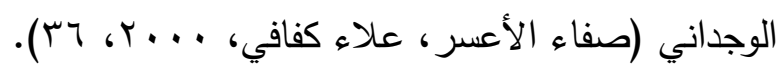

• التوقع المعياري: هي عملية يتم من خلالها وضع تصور للصورة المستقبلية المستهدف تحقيقها ثم محاولة وضع الخطوات والإجراءات التي من شأنها تحقيق هذا التصور المأمول.

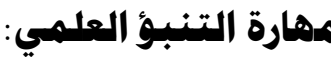

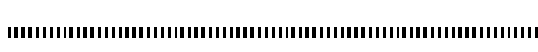
العدد مارس 99 r人

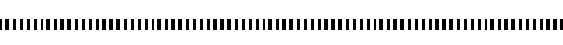
المجلد الخامس والعشرون 
تصميم وحدة في النانو تكنولوجي وتطبيقاتها قائمة على التعلم البنائي لتتمية مهارات التفكير المستقبلي

$$
\text { لناميذ الصف الثاني الإعدادي }
$$

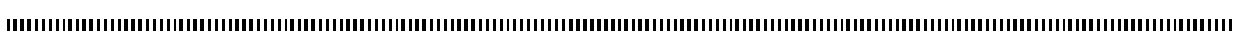

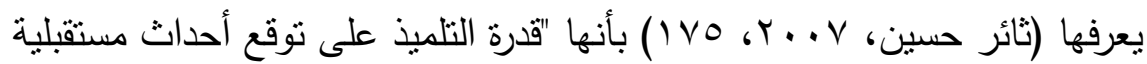

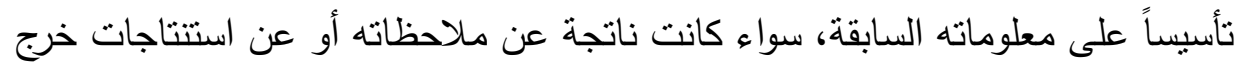

$$
\text { بها من تجارب معينة". }
$$

ويمكن تعريف التنبؤ بأنه "اجتهاد علمي منظم يعتمد على دراسة وفهم الماضي

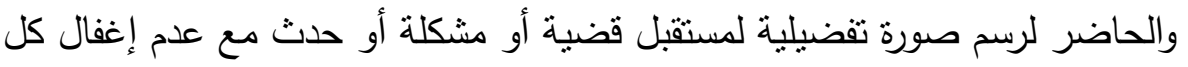

التشابكات المختلفة، وذلك من خلال صباغة مجموعة من التوقعات المحسوبة أو

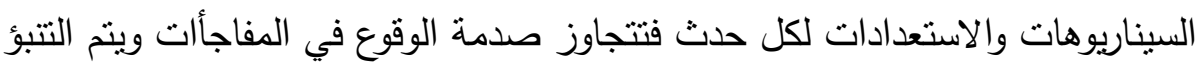
لفترة زمنية محددة يتم تحديدها مسبقاً" (محمد السيد، 9 . . ب).

\section{وهن المهارات الفروية لمهارة التنبؤ العلمي همارتي:}

• التنبؤُ الاستكثافي: هي العملية التي يتم من خلالها استكثاف الأحداث العلمية الممكن وقوعها في المستقبل عن طريق إدراك العلاقات والتفاعلات التي يمكن

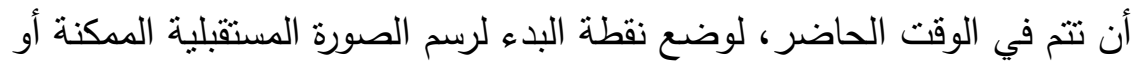

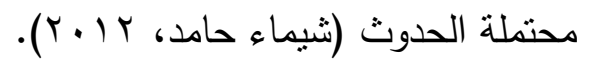

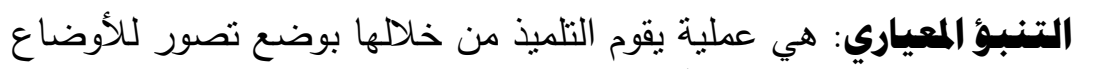
التي يتوقع التلمبذ في حدوثها مستقبلاً، وذلك من خلال تحليل الأوضاع الراهنة لتحديد الإجراءات التي ينبغي إتباعها للوصول إلى هذا الوضع المستقبلي المرغوب (الثيماء

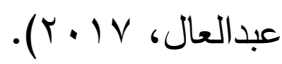

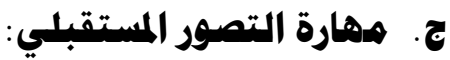

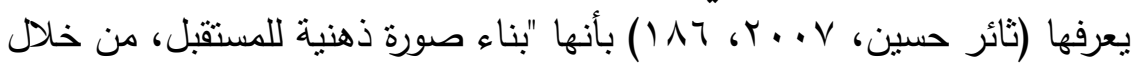

استحضار صورة من الماضي لإختراع أثنياء جديدة، ويستخدم للوصول إلى ما وراء الحقيقة والواقع، فهو مرتبط بالخيال أكثر منه بالواقع، فمن خلاله يستطيع التلميذ بناء

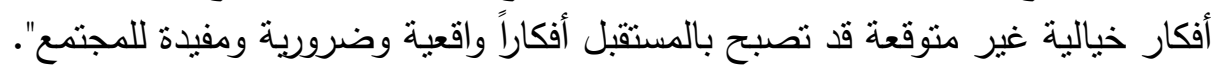

وبعرف "بيير وباري" (Beyer\& Barry, 1995, 297) مهارة التصور بأنها العملية التي يتم من خلالها تكوين صورة متكاملة للأحداث في فترة مستقبلية، وتتأثر هذه الصورة المستقبلية بعوامل الإبتكار ، الخلق، والخيال العلمي".

\section{وهن المهارات الفرعية لمهارة التصور المستقبلي ههارتي:}

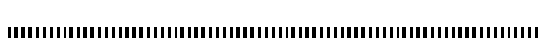

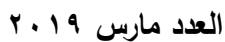

rq

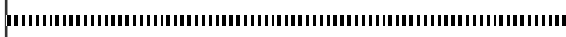
المجلا الخامس والعشرون 
تصميم وحدة في النانو تكنولوجي وتطبيقاتها قائمة على التعلم البنائي لتتمية مهارات التفكير المستقبلي

$$
\text { لناميذ الصف الثاني الإعدادي }
$$

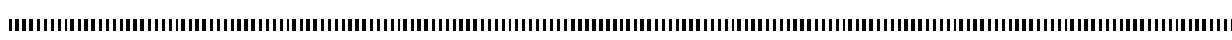

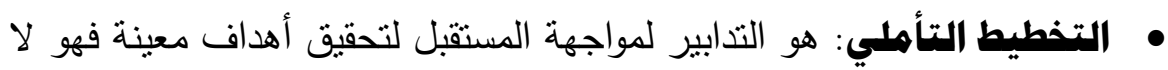

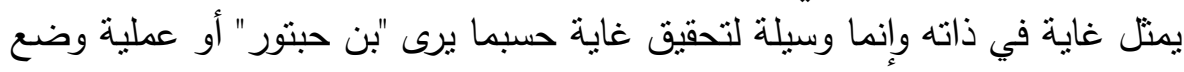

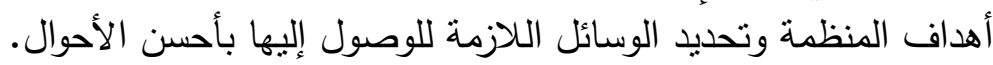

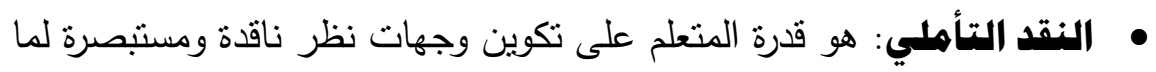
بطرح من موضوعات وأفكار ومشكلات مرتبطة بأحداث علمية مستقبلية متوقعة، ليتمكن من معالجة المواقف التعليمية التي تتطوي على هذه المشكلات من خلال وجهات نظر

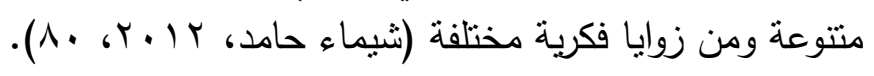

\section{المهور الرابع: اسمات تلاميذ المروحلة الإعدادية فلية}

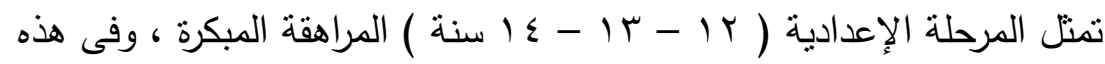
المرحلة يتضاءل السلوك الطفلي، وتبدأ المظاهر الجسمية والعقلية والانفعالية والاجتماعية

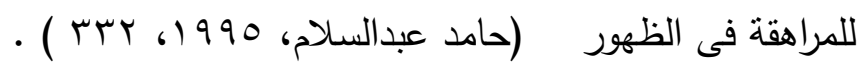

\section{أولا : النهمو العقلي المهرفي لتلهيذ المرحلة الإعدادية:}

تمتد هذه المرحلة من الحادية عشرة إلى الرابعة عشرة تقربياً ، وفي هذه المرحلة الثكلية أي مرحلة العمليات المجردة تتمو قدرة التلميذ على الانتباه لدرجة بستطيع معها

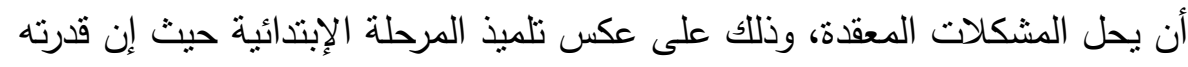

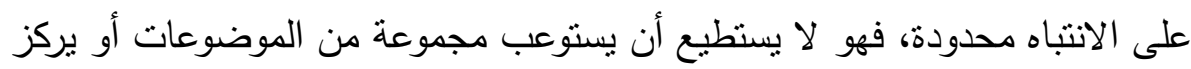

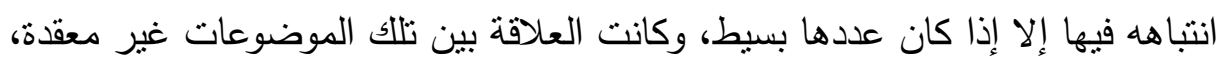

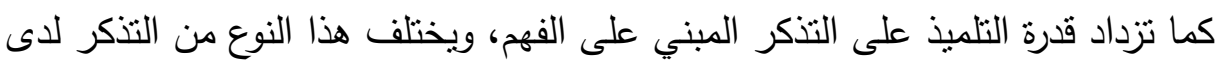
الطفل في المراحل السابقة، فتلميذ المدرسة الإبتدائية يميل إلى التذكر الآلي، أما تلميذ فيذ فئي

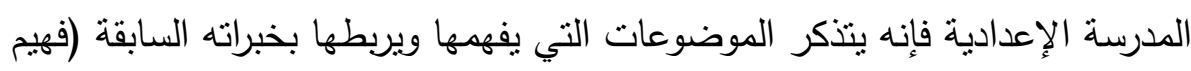

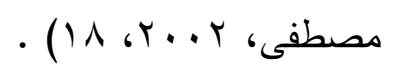

\section{ثانيا: النسمو الانفعالي لتلميذ المرحلة الإعدادية:}

تعتمد انفعالات المراهق على النمو العضوي والنمو العقلي، ويحقق المراهق فى في كليهما تطوراً كبيراً فالتغيرات الجسمية وما يتبعها من اضطراب في الحياة الحئ الانفعالية يساندها التقدم العلمي الذى وصل إلبه المراهق؛ تحول عالم المراهق إلى عالم زاخر

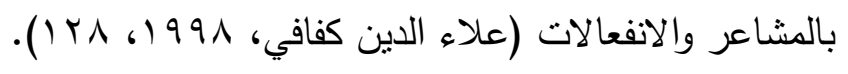

\section{ثالثًا: النهمو الاجتماعي لتلميد المرحلة الإعدادية:}

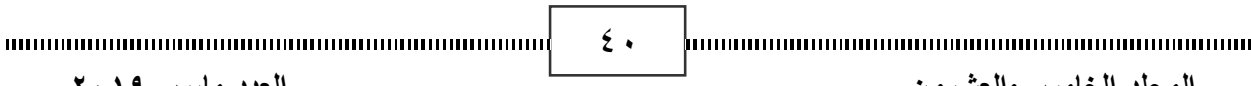

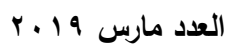
المجلا الخامس والعشرون 
تصميم وحدة في النانو تكنولوجي وتطبيقاتها قائمة على التعلم البنائي لتتمية مهارات التفكير المستقبلي

$$
\text { لتلاميذ الصف الثاني الإعدادي }
$$

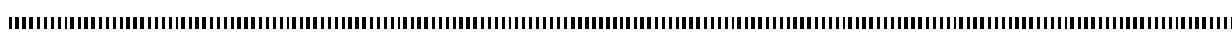

وفيها يبدأ المراهق إعداد نفسه ليكون مواطن متطبع اجتماعياً خلال هذه المرحلة، هال

$$
\text { وأهم ما يميز هذه المرحلة : }
$$

ا • يميل المراهق إلى مسايرة المجموعة التى ينتمي إليها.

r. استعداد المراهق لخدمة الآخرين وتقديم العون لهم.

ب. تتبدى المسئولية الاجتماعية فى سلوك المراهق، وذللك عندما بشارك فى

الأنشطة المدرسية.

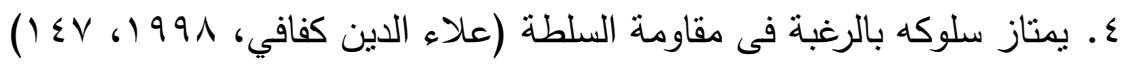

ه. التتافس من أهم أنماط التفاعل الاجتماعي بين أفراد الجماعة (فؤاد عبداللطيف،

$$
\text { وآمال أحمد، ... (r. (1). }
$$

\section{التجريب الميداني للبحث؛ وسار وفقًا للخطوات الآتية:}

ا ـ اختيار مجموعة البحث بطريقة عشوائية من تلاميذ الصف الثاني الإعدادي

(لتمثل المجموعة التجربيية) بإحدى المدارس الإعدادية التابعة لإدارة حلوان التعليمية بمحافظة القاهرة.

$$
\text { r . تحديد متغيرات البحث وضبطها. }
$$

ب. التطبيق القبلي لأداة البحث لمعرفة المستوبات المبدئية لتلامبذ المجموعة

$$
\text { التجريبية في متغير البحث التابع. }
$$

ع. القيام بتدربس الوحدة المصممة في النانوتكنولوجي وتطبيقاتها

للمجموعة التجربيية.

ه. التطبيق البعدي لأداة البحث لمعرفة مدى فاعلية المتغير المستقل

(الوحدة المصممة في النانوتكنولوجي وتطبيقاتها) على المتغير التابع (مهارات

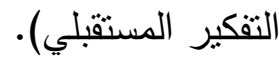

7 ـ تحديد أساليب المعالجة الإحصائية للبيانات والتوصل إلى النتائج

وتفسبرها.

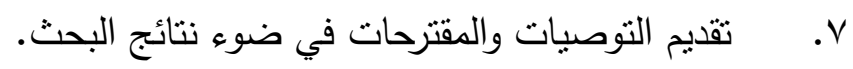

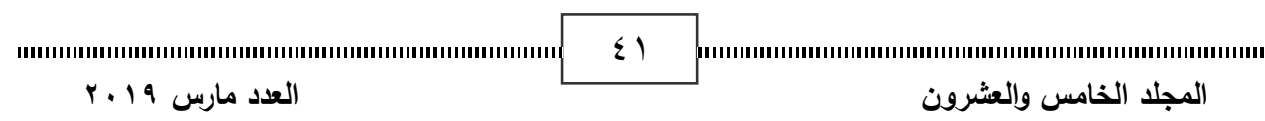


تصميم وحدة في النانو تكنولوجي وتطبيقاتها قائمة على التعلم البنائي لتتمية مهارات التفكير المستقبلي

$$
\text { لتلاميذ الصف الثاني الإعدادي }
$$

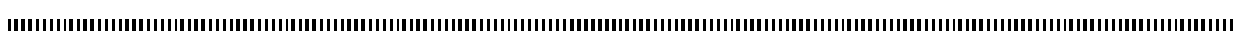

\section{نتائج البهث وتفسيرها:}

\section{أولاً: نتائج الفرض الأول الذي ينص على: يوجد فرق دال إحصائياً عند مستوى}

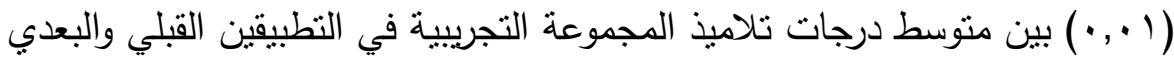
لمهارة التوقع الحدسي لصالح النطبيق البعدي.

ولاختبار صحة هذا الفرض تم حساب المتوسط الحسابي والإنحراف المعياري

لدرجات تلاميذ المجموعة التجريبية، وقيمة "ت" بين التطبيقين القبلي والبئي والبعدي لمهارة

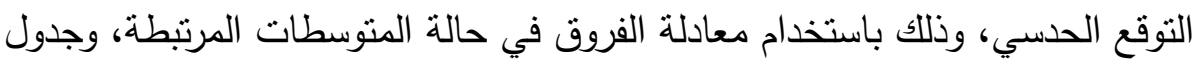

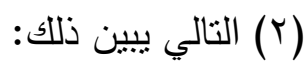

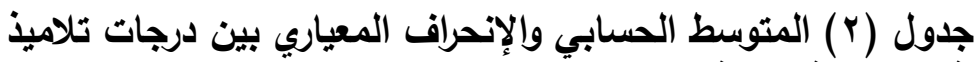
المجموعة التجريبية وقيمة "ت" ومستوى دلالتها بين التطبيقين القبلي والبعدي لمهارة

\begin{tabular}{|c|c|c|c|c|c|c|}
\hline مستوى الدلاية & قالمحسوية "ت" & الدرية & الإنحراف & المسابي & المهارة & التطبيق \\
\hline \multirow[t]{2}{*}{$\cdot, \cdot 1$} & \multirow[t]{2}{*}{ TV,r } & \multirow[t]{2}{*}{$\leq \varepsilon$} & $1, r$ & $0, r$ & \multirow{2}{*}{ الحسوقي } & القبلي \\
\hline & & & 1,0 & $r, 1$ & & البعدي \\
\hline
\end{tabular}

\section{ويتضح هن نتائج جدول (ז) السابق مها يلي:}

- ارتفاع متوسط درجات التطبيق البعدي عن متوسط درجات التطبيق القبلي لتلاميذ المجموعة التجريبية في مقياس مهارات التفكير المستقبلي (مهارة التوقع التوني

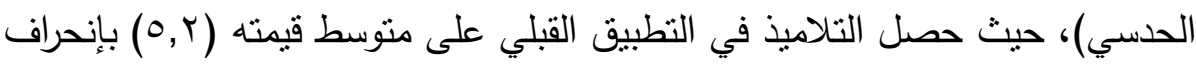

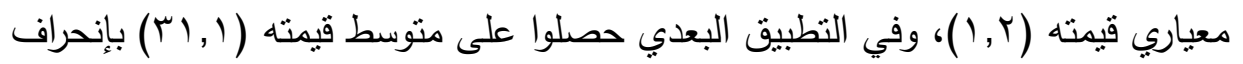

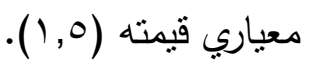

- قيمة (ت) المحسوبة لدلالة الفرق بين منوسط درجات تلاميذ المجموعة

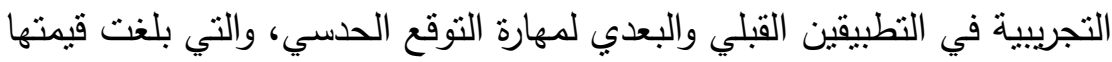
( )

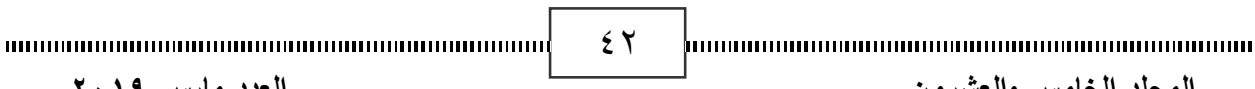

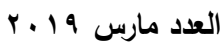
المجلا الخامس والعشرون 
تصميم وحدة في النانو تكنولوجي وتطبيقاتها قائمة على التعلم البنائي لتتمية مهارات التفكير المستقبلي

$$
\text { لتلاميذ الصف الثاني الإعدادي }
$$

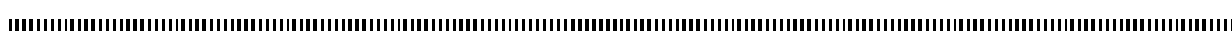

- وهذا بدل على وجود فرق دال إحصائياً عند مستوى (1 . . ) بين متوسط

درجات تلاميذ المجموعة التجريبية في التطبيقين القبلي والبعدي لمهارة التوقع الحدسي دودي

لصالح التطبيق البعدي.

ثانيًا: نتائج الفرض الثاني الذي ينص على: يوجد فرق دال إحصائياً عند مستوى دئ

(1 ( . • ) بين منوسط درجات تلاميذ المجموعة التجريبية في التطبيقين القبلي والبعدي التياي لمهارة التتبؤ العلمي المشروط لصالح التطبيق البعدي.

ولاختبار صحة هذا الفرض تم حساب المتوسط الحسابي والإنحراف المعياري

لدرجات تلاميذ المجموعة التجريبية، وقيمة "ت" بين التطبيقين القبلي والبعدي لمهارة التتبؤ العلمي، وذلك باستخدام معادلة الفروق في حالة المتوسطات المرتبطة، وجدول (r) التالي يبين ذلك: الكيك: ودلك

جدول (ب) المتوسط الحسابي والإنحراف المعياري بين درجات تلاميذ المجموعة

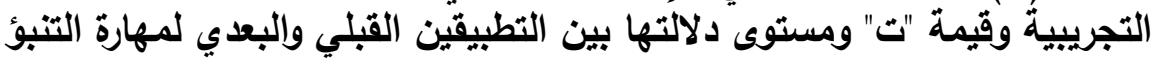

\begin{tabular}{|c|c|c|c|c|c|c|}
\hline الدلانة & قالمحسوية "ت" & درجة & الإنحراف & المتوسط & المهارة & التطبيق \\
\hline \multirow[t]{2}{*}{$\cdot, \cdot 1$} & \multirow[t]{2}{*}{$v_{4}, 1$} & \multirow[t]{2}{*}{$\leq \varepsilon$} & 1,1 & 0,7 & \multirow{2}{*}{ التلبؤ } & القبلي \\
\hline & & & $1, r$ & $r \cdot, 0$ & & البعدي \\
\hline
\end{tabular}

\section{ويتضح من نتائج جدول (r) السابق ما يلي:}

- ارتفاع متوسط درجات التطبيق البعدي عن متوسط درجات التطبيق القبلي

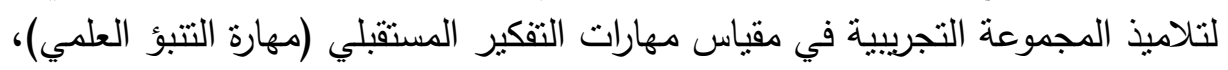
حيث حصل التلاميذ في التطبيق القبلي على متوسط قيمته (7, (0) بإنحراف معياري قيمته (1, (1)، وفي التطبيق البعدي حصلوا على متوسط قيمته (0, • (ب) بإنحراف معياري قيمته (1, (1, ) (1) (1)

- قيمة (ت) المحسوبة لدلالة الفرق بين متوسط درجات تلامبذ المجموعة التجريبية في التطبيقين القبلي والبعدي لمهارة التنبؤ العلمي، والتي بلغت قيمتها ( V7, (1) دالة عند مستوى الدلالة (1 ., •).

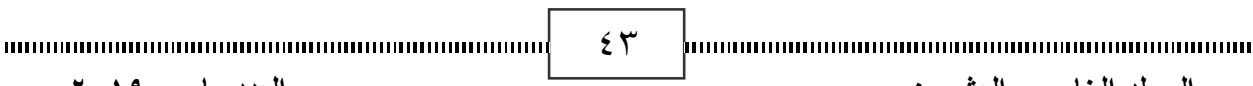

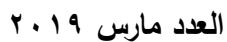
المجلد الخامس والعشرون 
تصميم وحدة في النانو تكنولوجي وتطبيقاتها قائمة على التعلم البنائي لتتمية مهارات التفكير المستقبلي

$$
\text { لتلاميذ الصف الثاني الإعدادي }
$$

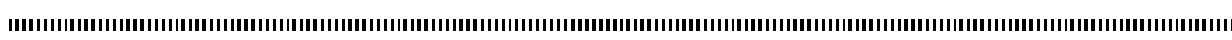

- وهذا بدل على وجود فرق دال إحصائياً عند مستوى (1 . . ) بين متوسط

درجات تلاميذ المجموعة التجريبية في التطبيقين القبلي والبعدي لمهارة التتبؤ العلمي

لصالح التطبيق البعدي.

ثالثًا: نتائج الفرض الثالث الذي ينص على: يوجد فرق دال إحصائياً عند مستوى

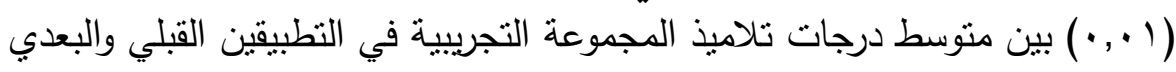
لمهارة التصور المستقبلي لصالح التطبيق البعدي.

ولاختبار صحة هذا الفرض تم حساب المتوسط الحسابي والإنحراف المعياري

لدرجات تلاميذ المجموعة التجريبية، وقيمة "ت" بين التطبيقين القبلي والبعدي لمهارة التوقع التصور المستقبلي، وذلك باستخدام معادلة الفروق في حالة المتوسطات المرتبطة، وجدول (ع) التالي يبين ذللك: لاهورك

جدول (ع) المتوسط المسابي والإنمراف المعياري بين درجات تلاميذ المبمومة

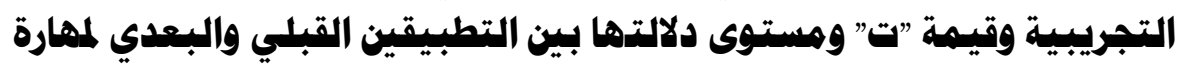

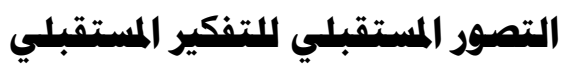

\begin{tabular}{|c|c|c|c|c|c|c|}
\hline مستوى الدلالة & قالمحسوية "ت" & الحرية & الإنعراف & الحسابي & المهارة & التطبيت \\
\hline \multirow[t]{2}{*}{$\cdot, \cdot 1$} & \multirow[t]{2}{*}{$V \Psi, \varepsilon$} & \multirow[t]{2}{*}{$\leq \varepsilon$} & $1, \varepsilon$ & $\varepsilon, 9$ & \multirow{2}{*}{ المستقبلي التصور } & القبلي \\
\hline & & & $1, r$ & Y & & البعدي \\
\hline
\end{tabular}

\section{ويتضح هن نتائج جدول (ء) السابق ما يلي:}

- ارتفاع متوسط درجات التطبيق البعدي عن متوسط درجات التطبيق القبلي

لتلاميذ المجموعة التجريبية في مقياس مهارات التفكير المستقبلي (مهارة التصور المستقبلي)، حيث حصل التلاميذ في التطبيق القبلي على متوسط قيمته (9, ؛ ) بإنحراف معياري قيمته (ع, (1)، وفي التطبيق البعدي حصلوا على متوسط قيمته (Tr) بإنحراف

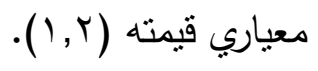

- قيمة (ت) المحسوبة لدلالة الفرق بين منوسط درجات تلامبذ المجموعة التجريبية في التطبيقين القبلي والبعدي لمهارة التصور المستقبلي، والتي بلغت قيمتها

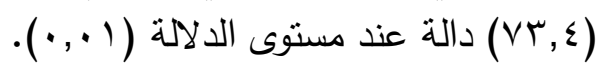

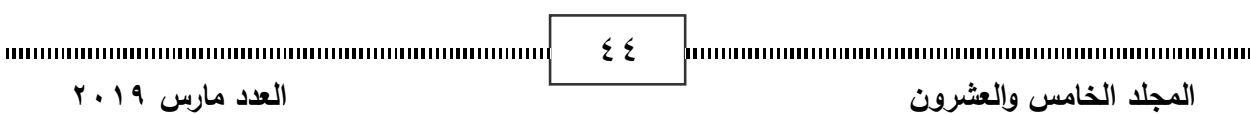


تصميم وحدة في النانو تكنولوجي وتطبيقاتها قائمة على التعلم البنائي لتتمية مهارات التفكير المستقبلي

$$
\text { لتلاميذ الصف الثاني الإعدادي }
$$

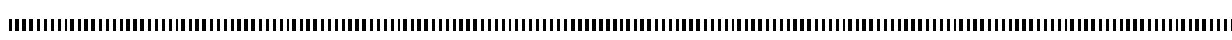

$$
\text { - وهذا يدل على وجود فرق دال إحصائياً عند مستوى (1 . . • ) بين متوسط }
$$

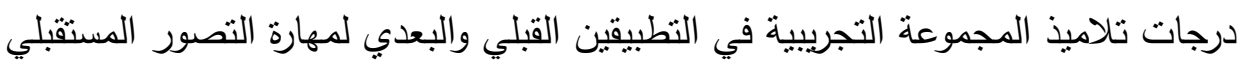
لصالح التطبيق البعدي.

رابهاً: نتائج الفرض الرابع الذي ينص على: يوجد فرق دال إحصائياً عند مستوى

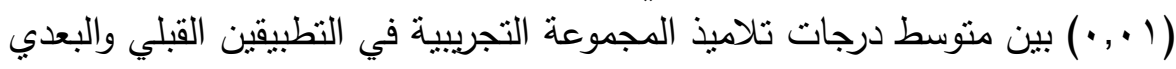
لمقياس مهارات التفكير المستقبلي ككل لصالح التطبيق البعدي.

ولاختبار صحة هذا الفرض تم حساب المنوسط الحسابي والإنحراف المعياري

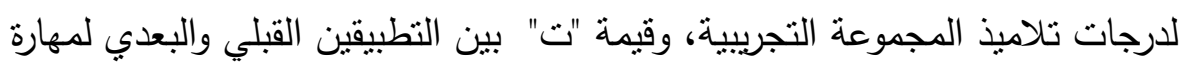

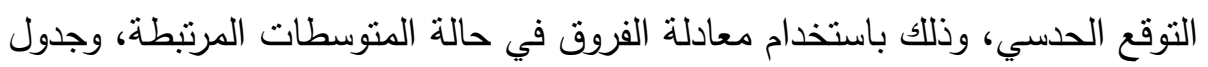

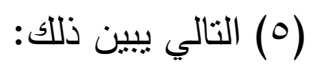

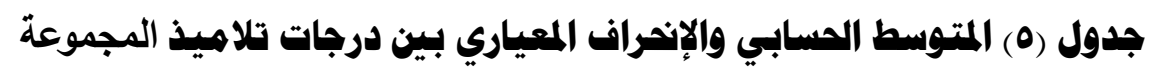
التجريبية وقيمة "ت" ومستوى دلالتها بين التطبيقين القبلي والبعدي لمهارئ دات التهات التفكير

\begin{tabular}{|c|c|c|c|c|c|c|}
\hline مستوى & قيمة "ت" & الدرية & الإنحراف & المستوسط & المهارة & التطبيق \\
\hline \multirow[t]{2}{*}{$\cdot, \cdot 1$} & \multirow[t]{2}{*}{$11 \wedge, r$} & \multirow[t]{2}{*}{$\leq \varepsilon$} & $r, 0$ & $10, V$ & \multirow{2}{*}{ مهارات المقياس } & القبلي \\
\hline & & & $r, V$ & $\wedge \vee, Y$ & & البعدي \\
\hline
\end{tabular}

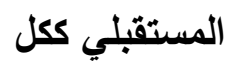

\section{ويتضح هن نتائج جدول (0) السابق ما يلي:}

- ارتفاع متوسط درجات التطبيق البعدي عن متوسط درجات التطبيق القبلي

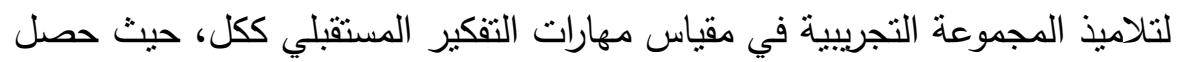
التلاميذ في التطبيق القبلي على متوسط قيمته ( $10, V)$ بإنحراف معياري قيمته (Y,0)،

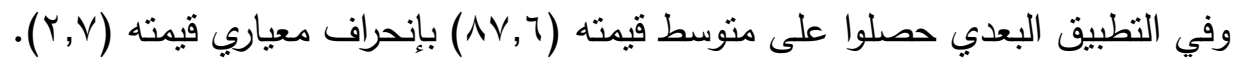

- قيمة (ت) المحسوبة لدلالة الفرق بين متوسط درجات تلاميذ المجموعة التجريبية في التطبيقين القبلي والبعدي لمقياس مهارات التفكير المستقبلي ككل، والتي

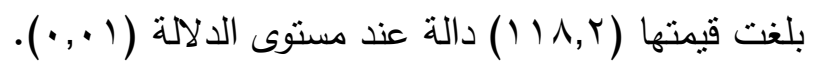

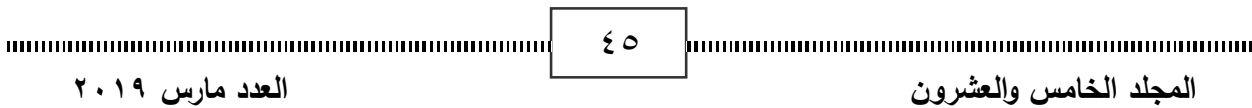


تصميم وحدة في النانو تكنولوجي وتطبيقاتها قائمة على التعلم البنائي لتتمية مهارات التفكير المستقبلي

$$
\text { لتلاميذ الصف الثاني الإعدادي }
$$

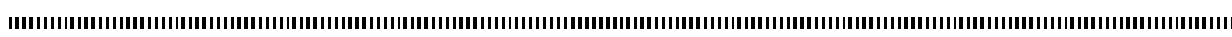

- وهذا بدل على وجود فرق دال إحصائياً عند مستوى (1 . , ) بين متوسط

درجات تلاميذ المجموعة التجريبية في التطبيقين القبلي والبعدي لمقياس مهارات التفكير المستقبلي ككل لصالح التطبيق البعدي.

\section{توصيات البـث:}

ا ـ أهمية وضرورة تضمين مفاهيم النانو وتطبيقات النانوتكنولوجي المختلفة في

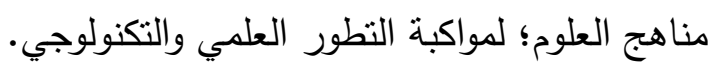

ץ. الاهتمام بالتلميذ فهو محور العملية التعليمية وذللك بمساعدته على بناء

المعلومات واكتساب المعارف الجديدة بنفسه من خلال طرق تدريس وأنشطة تعليمية متتوعة.

ب. الاهتمام بتنمية مهارات التفكير بوجه عام ومهارات التفكير المستقبلي بوجه خاص.

ع . إعداد برامج ومقررات دراسية للطالب المعلم بالثعب العلمية بكليات التربية

تختص بدراسة علم النانوتكنولوجي وتطبيقاته في المجالات المختلفة.

ه. عقد دورات تدريبية لمعلمي العلوم قبل وفي أثناء الخدمة لاكسابهم المعارف

والمعلومات والحقائق المتعلقة بعلم النانو وتطبيقاته التكنولوجية المستمرة في المجالات

المختلفة.

7 ـ ضرورة إثراء مناهج العلوم بأنشطة تساعد على تتمية مهارات التفكير المستقبلي

لدى تلامبذ مرحلة التعليم الأساسي.

\section{بموث مقترحة:}

ا ـ إعداد برنامج في النانوتكنولوجي وتطبيقاتها المختلفة لتنمية المفاهيم النانوية

$$
\text { لمعلمي العلوم قبل أو في أثناء الخدمة. }
$$

r. دراسة مستقبلية لتحديد أهم التطبيقات النانوتكنولوجية في المجالات المختلفة

$$
\text { التي ينبغي تتميتها لدى التلاميذ. }
$$

r. إعداد برنامج في النانوتكنولوجي وتطبيقاتها المختلفة لتتمية مهارات التفكير

$$
\text { المستقبلي للطالب المعلم بالثعب العلمية بكليات التربية. }
$$

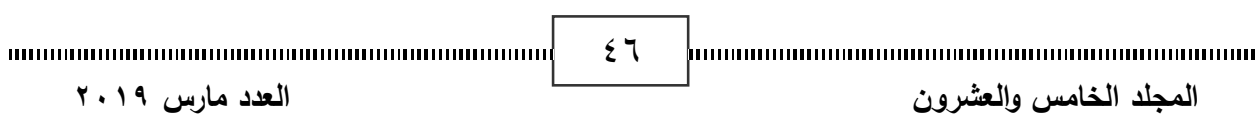


تصميم وحدة في النانو تكنولوجي وتطبيقاتها قائمة على التعلم البنائي لتتمية مهارات التفكير المستقبلي

$$
\text { لتلاميذ الصف الثاني الإعدادي }
$$

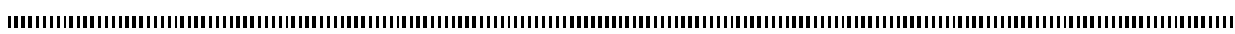

ع. دراسة مدى فاعلية استخدام أنشطة إثرائية قائمة على تطبيقات النانوتكنولوجي لتتمية مهارات التفكير المستقبلي لتلاميذ المرحلة الإبتذائية.

\section{المراجع}

\section{أولاً: المراجع العربية:}

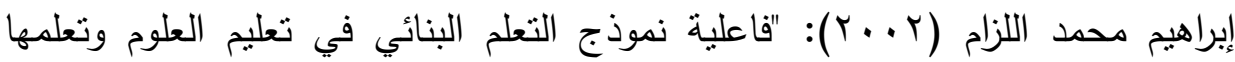

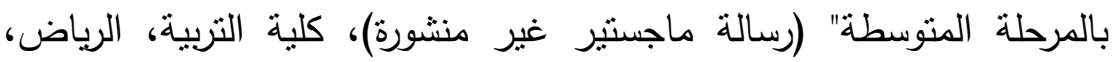
جامعة الملك سعود.

أحمد حجازي (r ( ا ب): تكنولوجيا النانو "الثورة التكنولوجية الجديدة"، الطبعة الأولى،

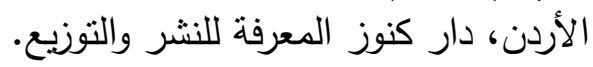

أحمد عوف محمد (T) (Y): "تكنولوجيا النانو وتطبيقاتها في الطب"، القاهرة، الهيئة المصرية للكتاب.

أمل إبراهيم لبد (YT): "إثزاء بعض موضوعات مناهج العلوم بتطبيقات

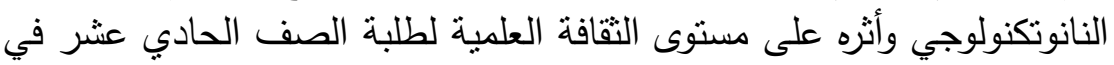

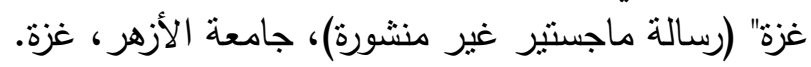

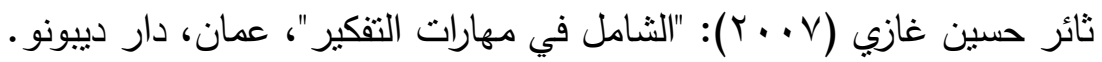
جيهان كمال السيد؛ وفوزية محمد الدوسري (ب . . ץ): "فاعلية نموذج التعلم البنائي في تعديل التصورات البديلة لبعض المفاهيم وتتمية الاتجاه نحو المادة لدى تلميذات

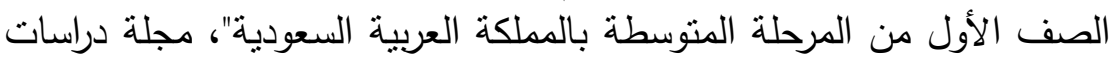

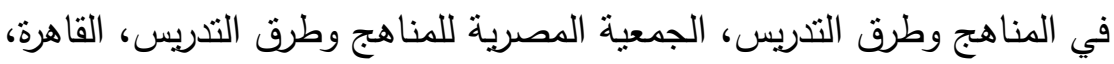
كلية التربية، جامعة عين شمس، العدد (9) (9).

حامد عبدالسلام زهران (990 (1)): "علم نفس النمو"، الطبعة الخامسة، القاهرة، عالم الكتب.

حسن حسين زيتون؛ وكمال عبد الحميد زيتون (Y9 99 ()): "البنائية منظور ابستمولوجي وتزبوي"، الطبعة الأولى، الإسكندربة، منشأة دار المعارف.

حمدي أبو الفتوح عطيفة (.99 (1)): "أسلمة مناهج العلوم المدرسية تصور مقترح"،

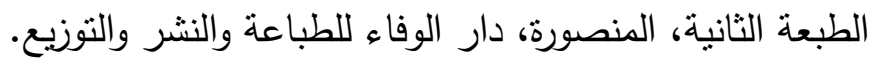

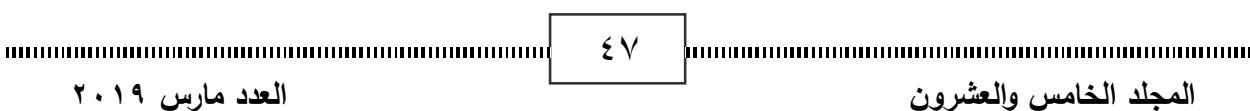


تصميم وحدة في النانو تكنولوجي وتطبيقاتها قائمة على التعلم البنائي لتتمية مهارات التفكير المستقبلي

$$
\text { لتلاميذ الصف الثاني الإعدادي }
$$

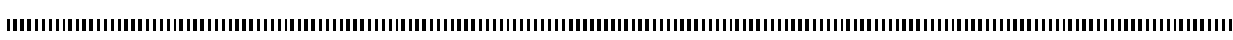
حمدي عبدالعظيم البنا ( ( . . ب): "تتمية مهارات عمليات العلم التكاملية والتفكير الناقد

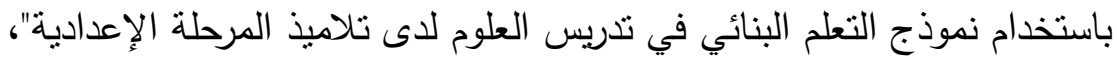

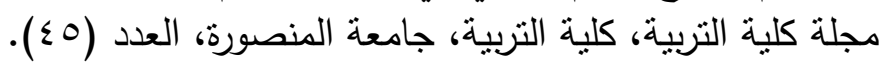
رمضان فوزي المنتصر (r/ (r): "وحدة مطورة لتتمية الحس التاريخي والتفكير المستقبلي لدى طلاب الصف الثاني الثانوي الأزهري" (رسالة ماجستير غيرة منشورة)، كلية التربية، جامعة طنطا.

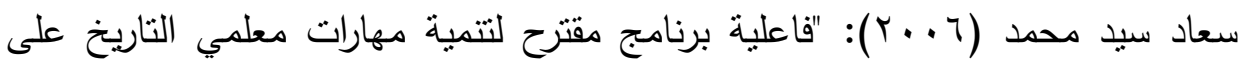

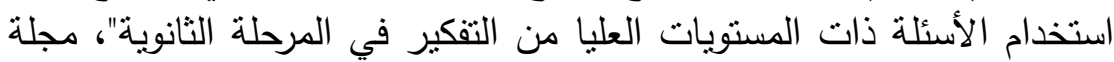

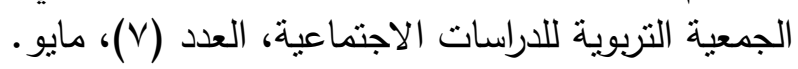

السيد محمدالسايح؛ ومرفت محمد هاني (9 . . r): تقويم منهج العلوم بالمرحلة الإعدادية

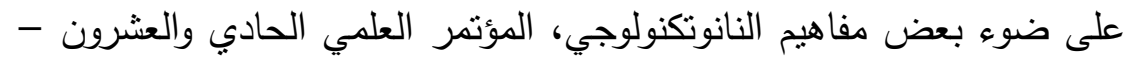

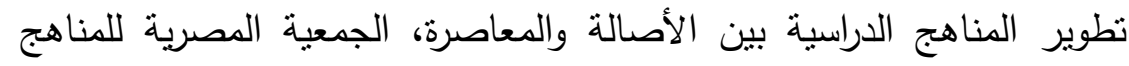

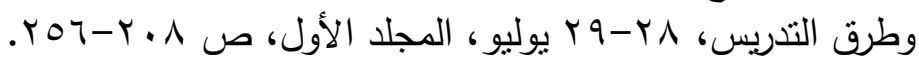

شيماء حامد عباس (r ( • r): "فاعلية مدخل قائم على الخيال العلمي في تدريس العلوم

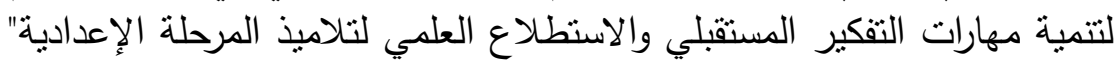

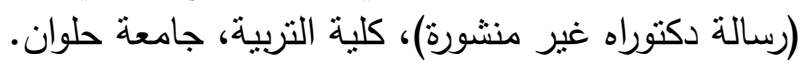

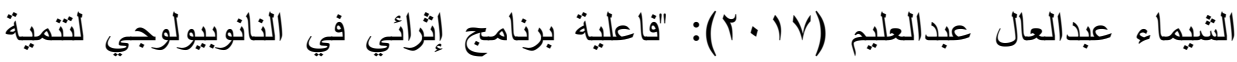
التفكير المستقبلي والثقافة النانوية لطلاب الصف الصف الأول الثانوي" (رسالة دكتوراه

$$
\text { غير منشورة)، كلية التربية، جامعة حلوان. }
$$

صفاء يوسف الأعسر؛ وعلاء الدين كفافي ( . . . ب): "الذكاء الوجداني"، القاهرة، دار

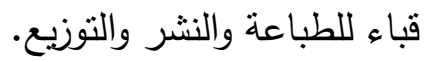

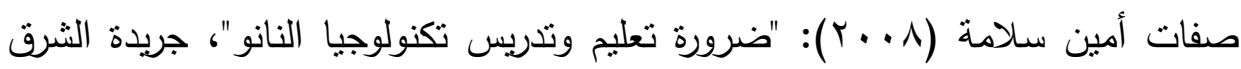

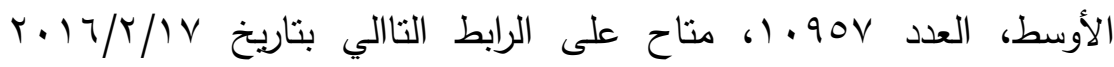

http://archive.aawsat.com/leader.asp?section=3\&issueno=10957

$$
. \& \text { article }=496628 \# . \text { VmLuouHGByw }
$$

صلاح أحمد مراد؛ وأمين علي محمد (r ( ـ r): "الاختبارات والمقاييس في العلوم النفسية

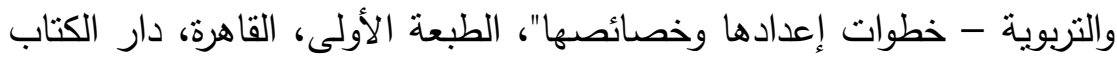

$$
\text { الحديث. }
$$

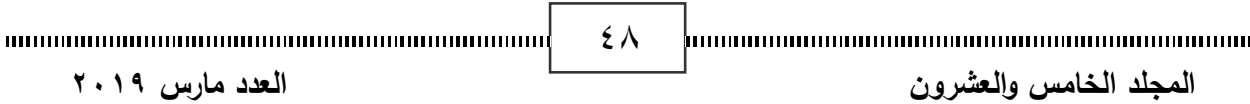
المجلد الخامس والعشرون 
تصميم وحدة في النانو تكنولوجي وتطبيقاتها قائمة على التعلم البنائي لتتمية مهارات التفكير المستقبلي

$$
\text { لتلاميذ الصف الثاني الإعدادي }
$$

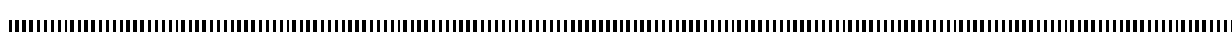
طارق بن طلق المطيري (r ( • r): "دور تقنية النانو في الحد من الكوارث"، ورقة عمل

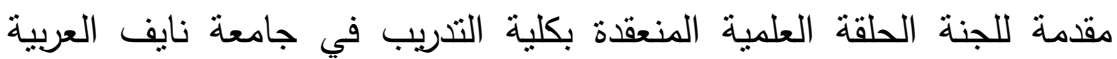

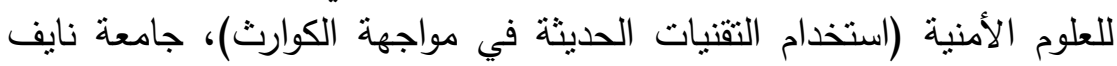

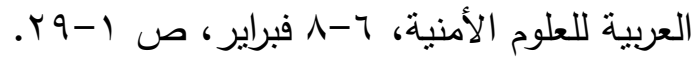
علاء الدين كفافي (1991 ( )): "رعاية نمو الطفل"، القاهرة، دار قباء. عماد حسين حافظ (9 . . ب): "اثر التفاعل بين أساليب عرض المحتوى ونمط الذكاء في تتمية مهارات التفكير المستقبلي في مادة الدراسات الاجتماعية لدى تلاميذ الدئ الحلقة الثانية من التعليم الأساسي" (رسالة دكتوراه غير منشورة)، كلية التربية، جامعة حلوان.

فتحي حمد شتوان ( • ( • ب): "علوم وتقنيات النانو : تطبيقاتها وآثارها وإستراتيجية تطوبعها

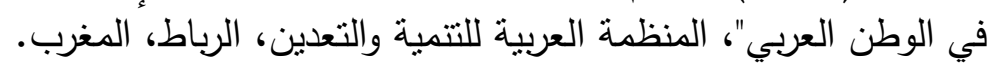

فهيم مصطفى (Y . . r): "مهارات التقكير في مراحل التعليم العام - رؤية مستقبلية للتعليم في الوطن العربي"، الطبعة الأولى، القاهرة، دار الفكر العربي.

فؤاد عبداللطيف أبو حطب؛ وآمال أحمد صادق ( . . . †): "علم النفس التربوي"، الطبعة

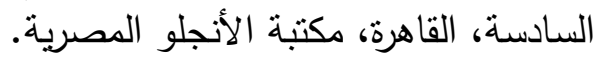

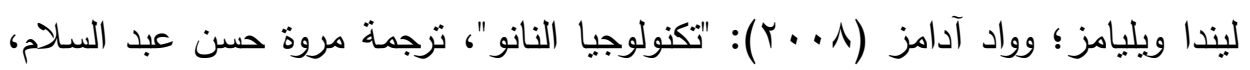
القاهرة، دار الفاروق للاستثمارات الثقافية.

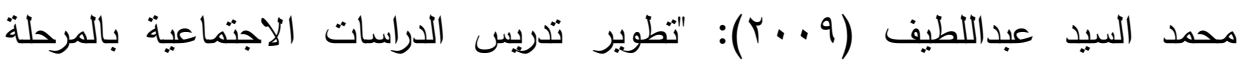
الإعدادية في إطار تحديات المستقبل" (رسالة دكتوراه غير منشورة)، كلية التربية، جامعة عين شمس.

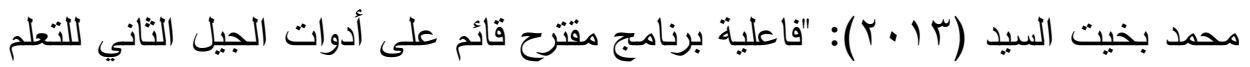
الالكتروني في تدريس الدراسات الاجتماعية على التحصبل المعرفي وتتمية

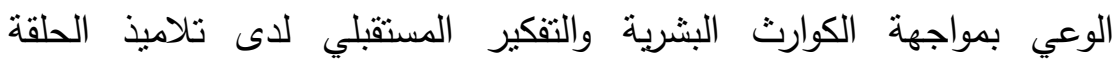
الإعدادية" (رسالة دكتوراه غير منشورة)، كلية التربية، جامعة سوهاج. محمد شريف الإسكندراني ( • ( ب): "تكنولوجيا النانو من أجل غد أفضل"، الكويت، عالم المعرفة.

|ก,น,

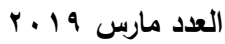

$\leqslant 9$

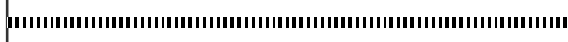
المجلد الخامس والعشرون 
تصميم وحدة في النانو تكنولوجي وتطبيقاتها قائمة على التعلم البنائي لتتمية مهارات التفكير المستقبلي

$$
\text { لتلاميذ الصف الثاني الإعدادي }
$$

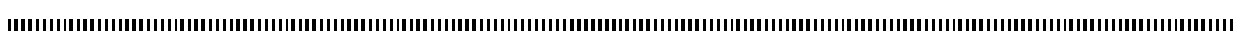
محمد غريب عميش (r ( r): "النانوبيولوجي عصر جديد من علوم الحياة"، القاهرة،

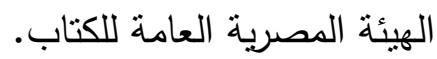

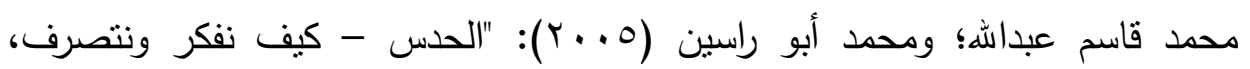

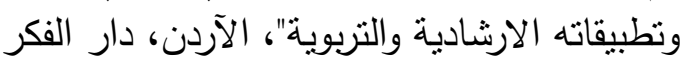

محمود محمد سليم (10 ب ب): "ثقنية النانو وعصر علمي جديد"، مدينة الملك عبدالعزيز

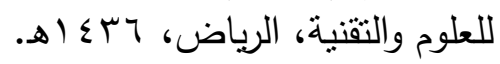

منى عبدالهادي سعودي (991 (1): "فعالية استخدام نموذج التعلم البنائي في تدريس العلوم على تتمية التفكير الابتكاري لدى تلاميذ الصف الخامس الإبتدائي"،

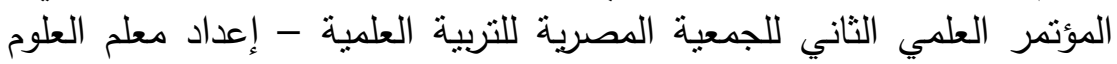

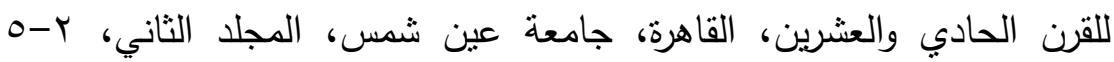

نوال محمد شلبي (Y ( • Y): "وحدة مقترحة لتتمية المفاهيم النانوتكنولوجية والتفكير البيني لاى طلاب المرحلة الثانوية"، الجمعية المصرية للمناهج وطرق اهنية التدريس، المؤتمر العلمي الثاني والعشرون للجمعية المصرية للمناهج وطرق التدريس -

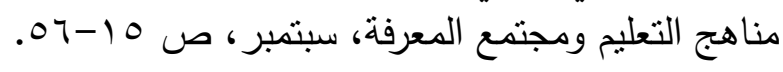

ياسمين خليل المحيمد (10 ب): "أثز استخدام نموذج التعلم البنائي في تتمية مهارات

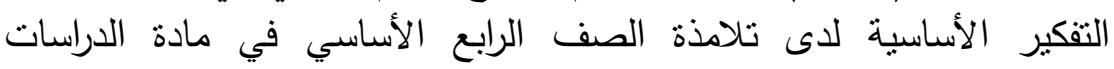

$$
\text { الإجتماعية" (رسالة ماجسنير غير منشورة)، جامعة دمشق، سوريا. }
$$

يوسف قطامي؛ وانتصار عشا (V . . r): "التفكير الحدسي للمرحلة الأساسية"، عمان، دان. دار ديبونو •

\section{ثانياً: المراجع الأجنبية:}

Beyer\& Barry, K. (1995): "Teaching Critical Thinking: Adirect approach", Scoial Education, vol. 49, no. (4), p.p. 297-303.

Brandt, R. (2000): "Education in Anew Erea", U.S.A, Association for Supervisor and Curriculum Development, Alexandria.

Delly, S.; Hutchinson, K. \&Bryan, L. (2007): “Incorporating Nano scale science and engineering concepts into middle and high school

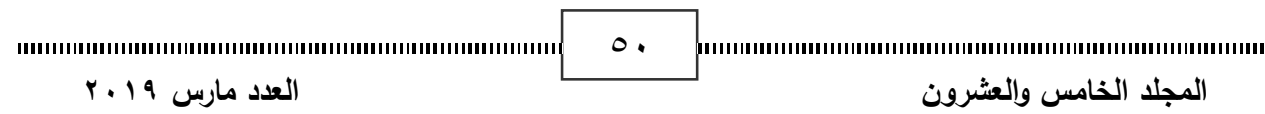


تصميم وحدة في النانو تكنولوجي وتطبيقاتها قائمة على التعلم البنائي لتتمية مهارات التفكير المستقبلي

$$
\text { لناميذ الصف الثاني الإعدادي }
$$

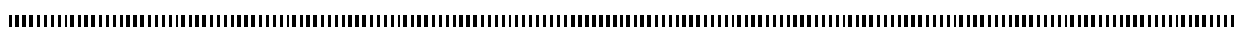

curricula", proceedings of the American Society for Engineering Education, at http:// www.naaturfagsenteret.no/binfil/download2.php?tid=1834143, ret $22 / 12 / 2014$.

Jane Page (1993): "Education Systeem as Agent of Change, (An Overview of Future Education), Slaughter R. New Thinking for New Millennium, London.

Laherto, T. (2010): Analysis of environmental significance of Nano Science and Nanotechnology in significant and technological literacy, Studies in Education Science, vol. 21, No. 2, P. 160-175.

National Nanotechnology Initiative (NNI) (2006): "What is Nanotechnology?" retrieved on 14-8-2015, from http://www.nano.gov.

Perkins, D. (1991):'Technology Meets Constructivism: Do they make a marriage", Educational Technology, Vol. 31, No. 5.

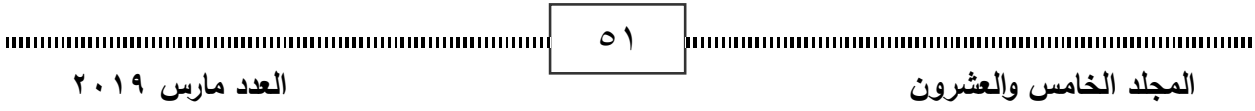

